\title{
Survey and Comparison of Floristic Diversity and Ethnic culture in Punikkolkavu and Chirakkakavu Sacred Groves of Thalassery, Kannur District, North Kerala, India
}

\author{
Article by Prathyusha. P., * V. Shabina \\ * Department of Botany Nirmala college for women, Coimbatore \\ E-mail Id: prathyusha.phd@gmail.com
}

\begin{abstract}
Sacred groves exist in various parts of the country and are unique examples of ecological understanding and management. These are locked information sites. The Sacred grove concept is one of the strategies developed by many human societies to conserve biological resources using a traditional approach. In the present study deals with the floristic comparison and ethnobotanical practices of the two sacred groves, Punikkolkavu and Chirakkakavu, Kannur District, Kerala. Punikkolkavu is rich in plant diversity when compared to Chirakkakavu. A total of 70 plant species belonging to 36 families were located in Punikkolkavu and 41 plant species belonging to 22 families were located in Chirakkakavu were recorded. The mode of mythological and therapeutical uses and conservation practices of these plants by the local people have been recorded.
\end{abstract}

Keywords: Sacred groves, Biological resources, Ethnobotany, Punikkolkavu and Chirakkakavu

\section{Introduction}

Biodiversity is the most valuable natural resource without which the overall development of man is not possible. Conservation and Management of Biodiversity is one of the foremost needs as vast expanses of vegetation continue to be under the threat of denudation and degradation all over the world. The western Ghats is one of the three biodiversity centers of India, which in turn is one of the 10 mega biodiversity centers of the world (Nayar, 1996), in which Kerala contributes a major part.

The Sacred grove concept is one of the strategies developed by many human societies to conserve biological resources using a traditional approach. Recognizing the importance of sacred groves, both in terms of conservation of biodiversity and cultural diversity, and in view of the threats faced by the groves, the Government of India has launched a Scheme 'Protection and Conservation of Sacred groves' within its programme 'Intensification of Forest Management'. As a part of this Central Government sponsored Scheme, the Department of Forests and Wildlife

Sacred groves are patches of natural vegetation dedicated to local deities and protected by religious tenets and cultural traditions; they may also be anthropogenic tree stands raised in honour of heroes and warriors and maintained by the local community with religious favours (Ramanujan and Cyril, 2003).Trees are a form of nature which represent life and the sacred continuity of spiritual, cosmic and physical worlds and are the first temple of gods (Frese et al., 1998). Trees may be 'holy', 'blessed' or 'sacred', depending upon the religious attitude of people towards them. A 'holy' tree is a species of which all parts are worshipped, e.g. Ficusreligiosa Lev. (peepal), Ficusbenghalensis L. (bargad).

Sacred groves also help in soil and water conservation, besides preserving biodiversity. The ponds and streams adjoining the groves are perennial water sources, and are often the only source for many of the animals and birds that make them their habitat, especially during summer. Sacred groves are extremely rich in floral and faunal elements. The origin of the groves is likely to have followed the introduction of agriculture. It is often believed that during shifting 
cultivation a part of the forest is left undisturbed. Here all the species found in the area are protected. These areas might have developed as sacred groves. Sacred Groves often protect watersheds and water sources. Groves are the result of the reasoned assertion rather than the instinctive behavior of the communities. The taboos, rituals and religious beliefs associated with the groves, supported by mystic folklore, have been the prime motivating factors for preserving the sacred groves.

North Kerala especially the district of Kannur is the pace of temples and folk arts. It is endowed with a number of temples with different worships and folk arts like theyyam. According to one version the name Kannur might have assumed its name from one of the deities of the Hindu pantheon, a compound of two words, Kannan(Lord Krishna) and Ur (place) making it the place of Lord Krishna.

Kannur district is known as the land of looms and lores, because of the number of looms functioning in the district and festivals held in temples. The district is the major centre of theyyam, a ritual dance of northern Kerala, and small shrines known as kaavu's associated with the theyyam dot the district. Many plant parts, flowers, plant extracts are used for theyyam. Every ritual performed in the temple is conducted very traditionally, for example many plants are not eaten before and during religious rites, some plants are used for achieving some specific rituals.

Many of the groves in kannur are bestowed with a rich variety of flora and vegetation. All activities of life in this land centre on trees and flowers. All forms of vegetation in these groves including shrubs and climbers are supposed to be under the protection of reigning deity of that temple and the removal of even a small twig is considered as taboo. The study of conservational practices according to their beliefs is an interesting area. This paper is the first record on the floristic composition and ethno botanical practices on the unreported sacred groves of Thalassery, kanuur district, Kerala.

The present study was undertaken to find the plant diversity in the selected groove and identify the plant species that are used for various religious purposes in the groves. No such study has been undertaken in these grooves so far. The specific objectives of the present study are, Preparation of an inventory of plant species conserved in and around the groves, Identification of various plants/plant parts used for religious purpose like Pujas as offerings etc., to study the religious, ritual practices and role of plants and study the mythology behind these practices.

\section{Materials and methods}

Extensive field visits were carried out to document the floristic diversity. The plants were collected and identified with the aid of regional floras, checklists and herbaria. Personal crossinterview with the local people and authentic literature reference were performed to ascertain the economic importance of the plants. Information of the historical background and social composition were collected from the revenue authorities and traditional leaders. The traditional beliefs, taboos, restrictions and folklores pertaining to the Grove are collected from villagers. Workers of Hindu religious department and devotes, inside the temple are crosschecked during worships and festivals were observed closely for corroboration and the field visits were timed accordingly.

The plant specimens were collected either in flowering or fruiting stage and photographs were taken from the study area. Further, specimens were processed as per routine herbarium techniques and deposited in department of botany, Nirmala college for women, Coimbatore. The specimens were identified with help of different floras, monographs, Gamble, revisions and other available literatures. Most of the information was collected from the elderly people, village head, and headman of the groves and also people with the diverse use of plants. 


\section{Study area}

In Kerala, based on management systems, sacred groves can be categorized into three types. They are, sacred groves managed by individual families, by groups of families and by the statutory agencies for Temple management (Devaswom Board). Area selected for the present study is North Malabar region of Kerala, located to the North east of Kerala within the geographical limit $11^{\circ} 18^{\prime}$ to $12^{\circ} 48^{\prime} \mathrm{N}$ latitude and $74^{\circ} 52^{\prime}$ to $76^{\circ} 07^{\prime} \mathrm{E}$ longitude, in Kannur district. Topographically the area consists of a narrow coastal belt, undulating midland and mountainous high range. The climate is typical warm-humid tropical type with mean temperature range of $22^{\circ} \mathrm{C}-37^{\circ} \mathrm{C}$ and relative humidity between $70 \%$ and $90 \%$. Studies were undertaken during November 2014 to March 2015 in Punikkol Kaavu and Chirakkakaavu sacred groves, both are located in Thalassery, Kannur District, Kerala (Figure-1)
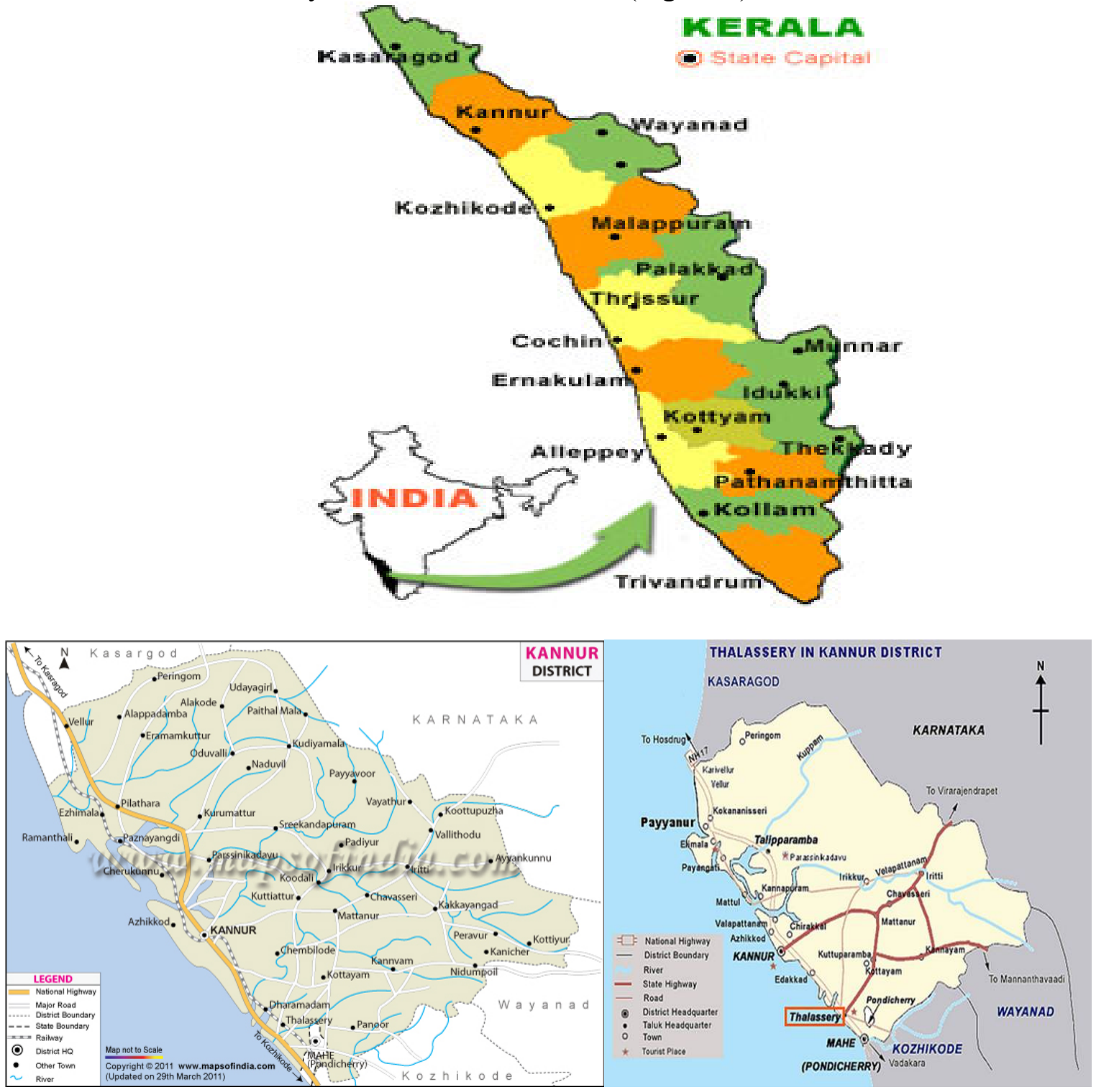

Figure 1 
South American Journal of Medicine

Special Edition 2016

\section{Results and discussion}

During the present study, sacred groves were visited frequently and plant species were documented. These culturally valued species are often ecologically important keystone species, which by their key role in ecosystem functioning contribute to support much biodiversity associated with it. Enumeration provides the list of plant species with scientific name of plants are represented in table 1 and table 2 . The primary motive behind the constitution of sacred groves is basically spiritual. However, these groves which doubled as biodiversity conservation areas have almost disappeared. Although the demolition of the groves started over 20 years ago, our results reveal that a greater percentage of them were demolished within the last decade.

The name of grove was given on the name of deity worshipped in the groves. The fruits of many species were used as food and also for performing various religious functions. The villagers also disclosed the fact that the soil in the sacred grove site remained more fertile than the adjacent sites of the village. This was possible due to high bio-mass and accumulation of high organic contents in such sites and further decomposition and nutrients release in such ecosystem.

Habitat fragmentation is a pervasive threat to forest ecosystems throughout the world, eventually leading to a decline in biological diversity and impairment of ecological processes. A number of studies in the last couple of decades have addressed the ecological, demographic and genetic consequences of small fragmented populations. These studies highlight the importance of a set of small groves in harboring the variability among them in an endemic and endangered species of both flora \& fauna. The present study is to compare the vegetation in two groves and survey the ethnic culture.

\section{Punikkolkaavu}

The presiding deity in this punikkolkaavuis Saasthappan, represents Lord Shiva. The codeities are Gulikan, Chaamundi and Rakthachaamundi. The grove has more than 100 years old. There is a place for Nagam in the Grove. Noorumpaalum is the main worship for Nagam and Pooyavaykkal is the main worship for Saasthappan.

The Grove has large vegetation around an area of one acre. These plants are protected because of some believes. 70 plant species belonging to 36 families were located from the Grove and these are tabulated in table 1. Photos of some plants also included (plate1-4). The plant families dominated are Fabaceae with 6 species, Lamiaceae with 5 species, Asteraceae with 4 species etc. The plant diversity includes Climbers, Herbs, Shrubs, and Trees etc. These are plotted in a graph (Figure 1). Herbaceous plants were dominated over other life forms representing 22 species followed by trees, 15 species shrubs 14 species etc. Only one fern can be located. The population is largely concentrated in Mimosa pudica, Caryotaurens, Cocosnucifera etc. Some plants like Musa, coconut areca etc are cultivated.

All plant species except one or two are economically important and almost $90 \%$ plants are used as medicine by indigenous people. (Figure2) shows the percentage of plant parts used by people for various purposes, mostly entire plant is used. Several Sacred plants are there in the Grove. They are Ocimum, Champaka, and Strychnosetc. Different plants are used for worshipping the God (Plate 8 a.) Tender leaves of coconut are used to prepare Thirumudi of Theyyam and also ornaments during the festival (Plate 8 b.).

\section{Chirakkakavu}

The presiding deity of this temple is the goddess Kali, who is worshipped in three forms, or Thrigunaathmika. The temple was built by the king of Kolathiri- Chirakkkal Raja after the swayambhoo of the goddess in Koduvally River, and so became renowned as Sree Chirakkakavu. Guntur Kottavaanavar, Ilankarumakan and Poothadi are in a single shrine near the 
temple. Outside the Nalambalam there is a Sarppakkavu (Snake Shrine) in the north-west corner of the temple which contains Nagaraja, Nagakanyaka and Chithrkoodam.

In this Grove the plants are conserved more than one acre area. It is tabulated (Table2). 42 plant species belonging to 22 families were located. The plant families dominated are Fabaceae and Asteraceae. Here trees are dominant over other life forms. Figure 3 shows the graph of species diversity. Most common tree is Ficus (Plate 9 a.). These are protected in a large area. The area is very cool also. Some rare plants are located here. One of the rare plants that can be seen in the Grove is Rudraksha. It has several medicinal uses. Also this plant is considered as Sacred. Most of the plants are economically important. They are used as medicine to cure various diseases. Percentage of plant parts used was represented by pie diagram (Figure4).

When compared with Punikkol Kavu, the number of plants is lesser in Chirakkakavu. That is plant diversity is higher than Chirakkakavu. But the number of species is higher there. For instance large numbers of Ficus plants are protected in a large area. Rare plants were located in both Groves. The plant diversity includes climbers, herbs, shrubs, trees etc. In diversity trees are dominant in Chirakkakavu, where as herbs are dominant in Punikkolkavu. Different plants and their used were tabulated. A rare tree seen in Chirakkakavu is Rudraksha. Its seed is considered as sacred. Some plants are common in two Groves. These include Cocosnucifera, Mangiferaindica, Mimosa pudica, Pothosscandens, Tectonagrandis, Strychnosnux-vomica, Heliotropiumindicum etc. Most of the plants located from the Groves are economically useful. Among them most have medicinal importance. Of these entire plant is used more as medicines. Both the Groves are associated with pond.

Festivals are celebrated in two Groves. The difference is that the main Deity in Punikkolkavu is Sasthappan and that in Chirakkakavu is Devi. The other Deities are also different in these two Groves. These Groves plays a very important role in maintaining the unity of the village people and also the traditional culture. Some plants in both the Groves are considered as Sacred (Table $3)$. These plants are protected on the basis of some believes.

The present findings are comparable with other studies in Sacred Groves of Kerala. The floral diversity in fresh water and salt water Sacred Groves was compared by Deep mol and Khaleel in Kannur district. Variation in species was reported by them. Ethno botanical study about medicinal plant was done by Harsh et al., reported a variety of plants and it was represented by Graph and Pie diagram. Similar studies are following. Chandrashekara and Sankar (1998) recorded 73 species from 3 Sacred Groves, Subrahmanya Prasad and Raveendran (2013) documented 187 vascular plants from Niliarkottam Sacred Grove in Kannur district. Divya and Manonmani reported 50 plant species from Sacred Groves of Nemmara in Palakkad District. Similar studies were done in other States also.

\section{Ethnic culture}

In both the Groves festival is celebrated every year. Different plant parts were used for worshipping God and also for making thirumudi and ornaments of God during festival. Mainly tender leaves of coconut were used.

\section{Punikkolkavu}

Each year festival is celebrated during December. During festival Theyyam will be there. Theyyam is a corrupt form of Daivam or God. People of this district consider Theyyam itself as a God and they seek blessings from this Theyyam. 
South American Journal of Medicine

Special Edition 2016

\section{Gulikan}

Guligan Theyyam is worshipped as the Lord Shiva. In every Kaliyattam, the performance of Guligan Theyyam is inevitable. The 'Kanhiram' and 'Chempaka' are important for Gulikan. The story behind Guligan is following.

Once there was a saint, who was a great devotee of God Shiva. He has no children. As a result of continuous prayer, God blessed him with a child, who was very intelligent and smart. But God remind him that his son will live only up to 18 years old. Thus the child born and he was named Markandeya. He grew up as a great devotee of Shiva. When he attains 18 years the God of death (Yama) came to kill him. But he ran and tightly hold the Shivalinga. But the God of death tried again to take the boy along with Him. God Shiva gets angry and He killed the God of death by the power of His third eye. After this there is no death occur in the earth. So the Goddess of earth (Bhoomi Devi) could not bear the weight and She went to Shiva for a solution. Thus He creates another God of death named Gulikan.

\section{Vishnumoorthi (Chaamundi)}

An inevitable constituent in a majority of the Kaliyattams is the performance of the Vishnumoorthi Theyyam and its performance includes complicated rites and rituals. The peculiar drum-beats can be heard up to a distance of $2 \mathrm{~km}$ from where the performance of the Vishnumoorthi Theyyam takes place. The enactment involving the Narasimha Avathara of Lord Vishnu by the Koladhari especially thrills the devotees and the spectators as a result of the body movements involved in it. More than a Myth describes the origin, features, rites, centres of worship etc of the Vishnumoorthi Theyyam.

\section{Kuttichathan (Sasthappan)}

Kuttichathan's mythological story is very impressive and a hyperbole. The 'Lord Shiva' and his wife 'Devi Parvathi' were staying in a remote hill area along with 'Valluvar' communities. The 'Lord' had two children with 'Valluvathi, ie,'Karuval' and 'Kuttichathan'. The later born in a peculiar manner with flower on his forehead, a third divine eye and a black body with long white stripes. There lived a 'Kalakadu Namboothiri'; his wife did not conceive a child. As a result of his prolonged fasting the 'Lord' decided to donate second child of 'Valluvathi' to the Namboothiri family. The child had his early education and was showing certain mischievous acts during his childhood. He even beheaded the cows and drinks its blood to quench his thirst. They felt his actions were beyond their endurance and they killed him.

But even after his death they could hear the unbodied sound of him reverberating inside their 'Illam' (House). To get rid of his disturbances they conducted ceremonial fire 'Kuttichathans' were is emerging. It was 'Chalaperumalayan' alloted certain land for the construction of 'Sthanas' for 'Kuttichathan' and they started to perform the theyyakolam.

\section{Chirakkakaavu}

The temple festival is celebrated every year on days 9-12 of the month of Medaom which usually falls on April 22 to 25th. On Medom 9th the than trikpoojas and Uthsavabali is observed. In the evening the Uthsalvakolam (Thidambu) is taken out of the temple as Ezhunnallathu by the temple priest. This occasion is the only time where the goddess comes out of the temple in full alankaras in UlthasavaThidambu. Bhagavathi, Puthiya Bhagavathi and Cheriya Thampuratty, are the daughters of the mother goddess and Valiya Thampuratty. Guntoor Kottavanavan, Ilankarumakan, Poothadi are the other male Theyyams here. On Medom 10th the Nattathira is celebrated here. On $11^{\text {th }}$ MedomAriyalavu is observed. This is a practice of giving rice. 


\section{Theyyam}

This is the next three-day festival. The four manifestations of the goddess, Chorakalathil pulses and coconut oils to the all concerned communities to the kavu. This custom recalls the riches of bygone times. In the olden days, the Temple owned land from Vamla to Kali. In the morning of 11th medom Valaiya Thampuratty visits all devotees in the village (hosuses comes under Anchukandy Parambu) and blesses the devotees.

Kalasams come from various parts of the villages to make offerings to the Devi. MothaKalasam and Vaikalasam have the right to enter to the temple first. By the early hours of 12th Medom. The Theyyams start to come to the Thirumuttam in this order: Guntoor Kotta Vanavar, Chorakalathil Bhagavathi and Puthiyabhgagavathi. It is considered a blessing when a few drops of rain sweep through as Chorakalathilbhagavthitheyyam appears on the courtyard of the temple. A Mulla Mala (Jasmine garland) is the traditional offering to ChorakkalathilBhagavathi. Thirdly comes the Theyaam of PuthiyaBhagavathi (Theethira), the Theyaam comes with the fire as ornaments and blesses the devotees. By the morning of 12th Medom the theyyam of Ilankarumankan and Poothadi appears on the courtyard of the temple. The theyyam is of divine war between the two. This theyyam makes us to recollect the thought of Bali-Sugreeva war.

Then Thampuratty comes out into the courtyard. The Aattam of Thampuratty with her divine sword is a very rare sight which gives her devotees a life's blessings. Then the Cheriya Thampuratty appears on the courtyard of the temple with beautiful white hair and other decorations. Then there Thampuratty with Thirumudy and her daughter, Cheriaya Thampuratty travel around the temple, followed by the kalasalams and devotees in procession

\section{Conclusion}

Sacred Groves are one of the examples of traditional conservation practices of plants. These are patches of natural, near-climax vegetation managed as a part of local cultural tradition and dedicated to certain Deities. Any form of cutting or removal of trees or their parts in the Grove is prohibited, lest it should invite calamities.

The present study is an attempt to compare the floristic diversity in two Sacred Groves and also survey about the ethnic culture. The study reveals that Sacred Groves are rich sources of medicinal plants with many rare species. Sacred Groves are the seat of rare and endangered species of plants. These are being preserved because they encompass village Gods within the Grove, which are worshipped as religious beliefs and taboos of the people weaken, the pressure of these forest increases. The study establishes the role of Sacred Groves in conserving the biodiversity.

Two groves are compared and found most of the plants are common in both the Groves. The species diversity in two Groves are tabulated. Punikkolkavu is rich in diversity when compared to Chirakkakavu.70 plant species belonging to 36 families were located from Punikkolkavu and 41 plant species belonging to 22 families were located from Chirakkakavu. Different habits of plants were plotted by using graph. Percentage of plant parts used is also represented by using pie diagram. In both the Groves plants were seen in which mostly entire plant is used. Also some plants are peculiar in each Grove. In punikkolkavu, herbs are occurred in larger number and in Chirakkakavu trees are larger number. Most of the plants have economic importance, especially medicinal values. Some plant parts like tender leaves of coconut are used during festivals for making Thirumudi and ornaments of God. Some plants are considered as Sacred. These plants are protected and worshipped.

Festivals were celebrated every year. This will helpful for maintaining unity between the people in the village. These Groves also plays an important role in controlling pollution, 
South American Journal of Medicine

Special Edition 2016

conserving medicinal plants, maintaining unity of the society etc. Thus Sacred Groves are an inseparable unit of our culture.

\section{References}

[1]. Chandrashekara.U.M, and Sankar.S (1998) Ecology and management of Sacred groves in Kerala: Forest ecology and management.112; 165-177.

[2]. Divya. K.R and Manonmani. K (2013).Floristic composition and ethanobotanical practices of the Sacred Groves of Nenmmara, Palakkad District, Kerala: International Journal of Pharmaceutical Sciences and Business Management.Vol.1 Issue. 1, September- 2013, pg. 9-17

[3]. Freseet al., Frese, P. R. and Gray, S. J. M. Trees (1998). In The Encyclopaedia of Religion (ed. Eliade, M.), Macmillan Library Reference USA, IBH Publishing, New Delhi. 1998, 397 - 414.

[4]. Nayar, M.P (1996).Hot spots of endemic plants of India, Nepal and Butan.

[5]. Ramanujam. M.P. and Cyril, K.P.K. (2003).Woody species diversity of four sacred groves in the Pondicherry region of South India. Biodiversity and Conservation 12: 289 - 299.

[6]. Subrahmanyaprasad K. and Raveenran K.(2013);Floristic diversity in Niliarkottam Sacred Grove in Kannur District, Kerala, India. Life sciences leaflets 1:64-73.

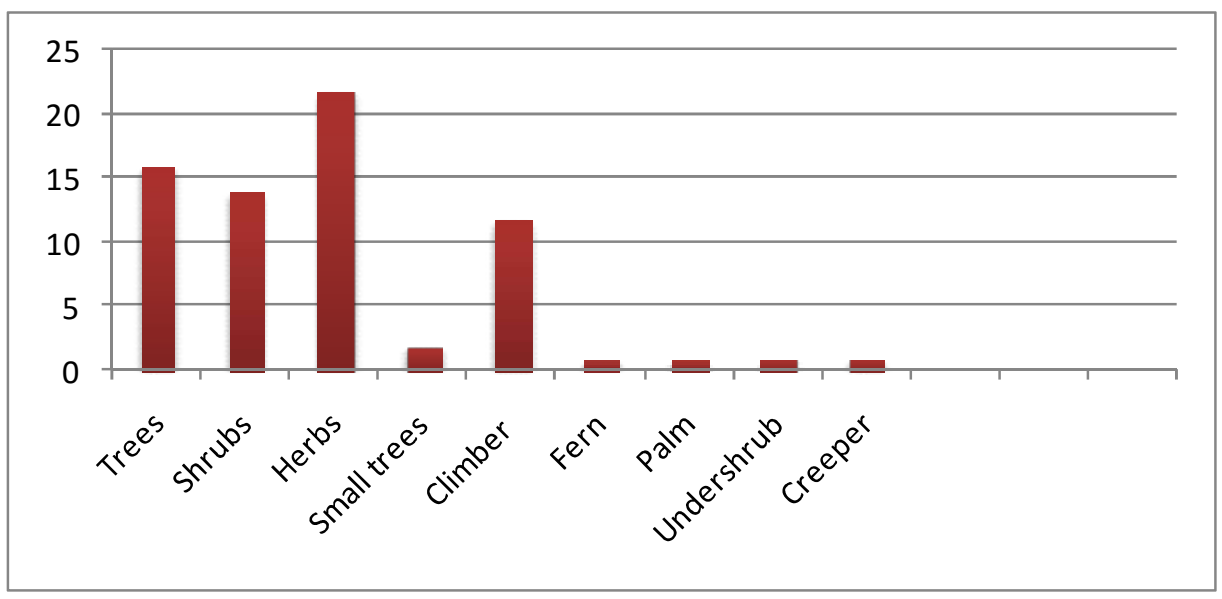

FIGURE 2: Species diversity in punikkol grove

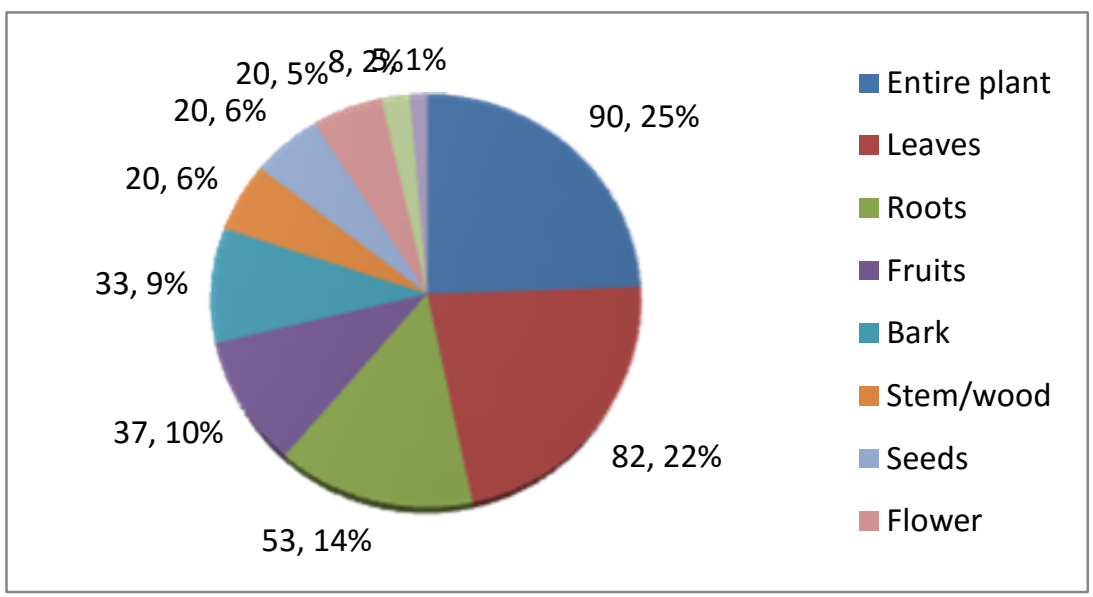

FIGURE 3: Percentage of plant parts used 


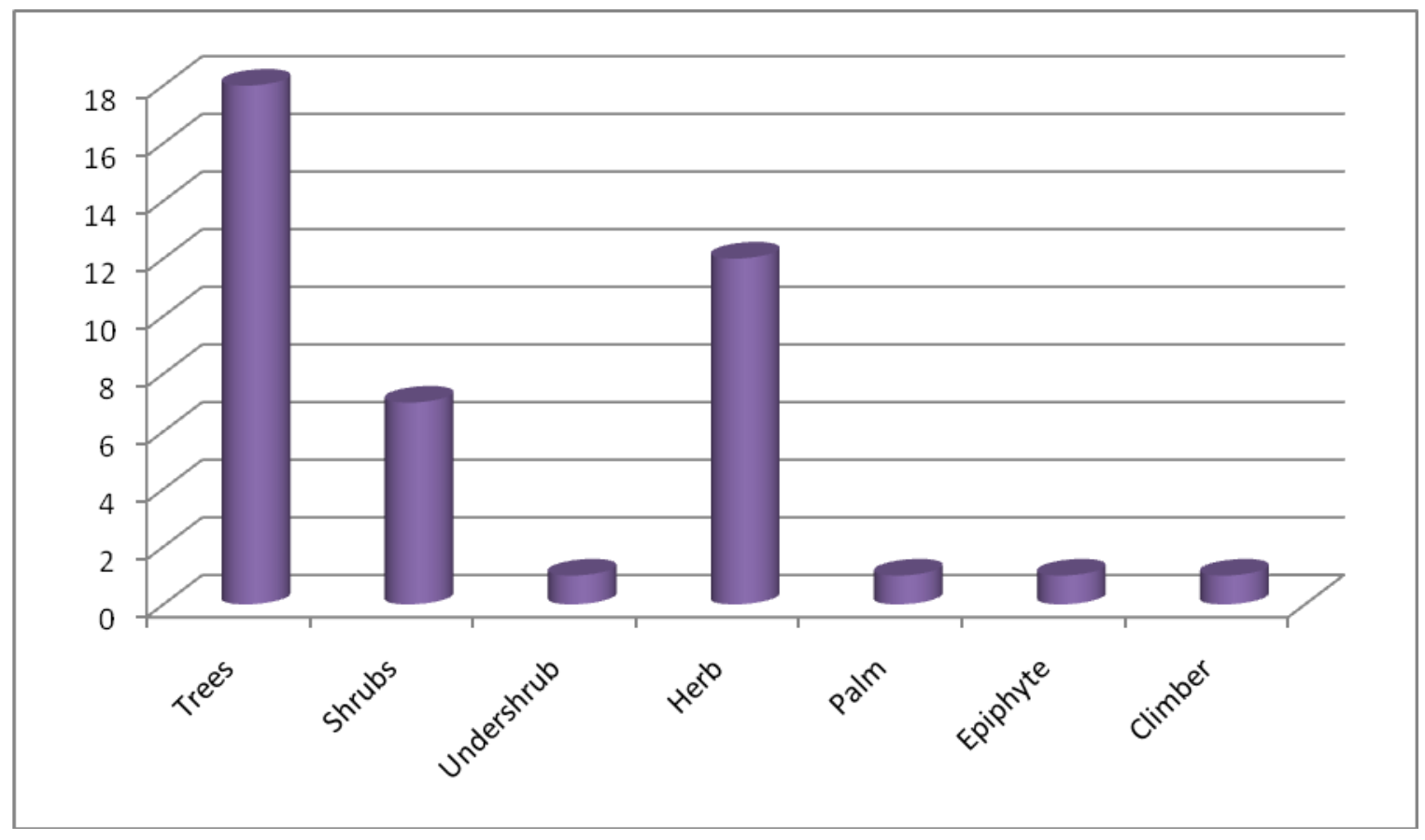

FIGURE 4: Species diversity in chirakkakavu

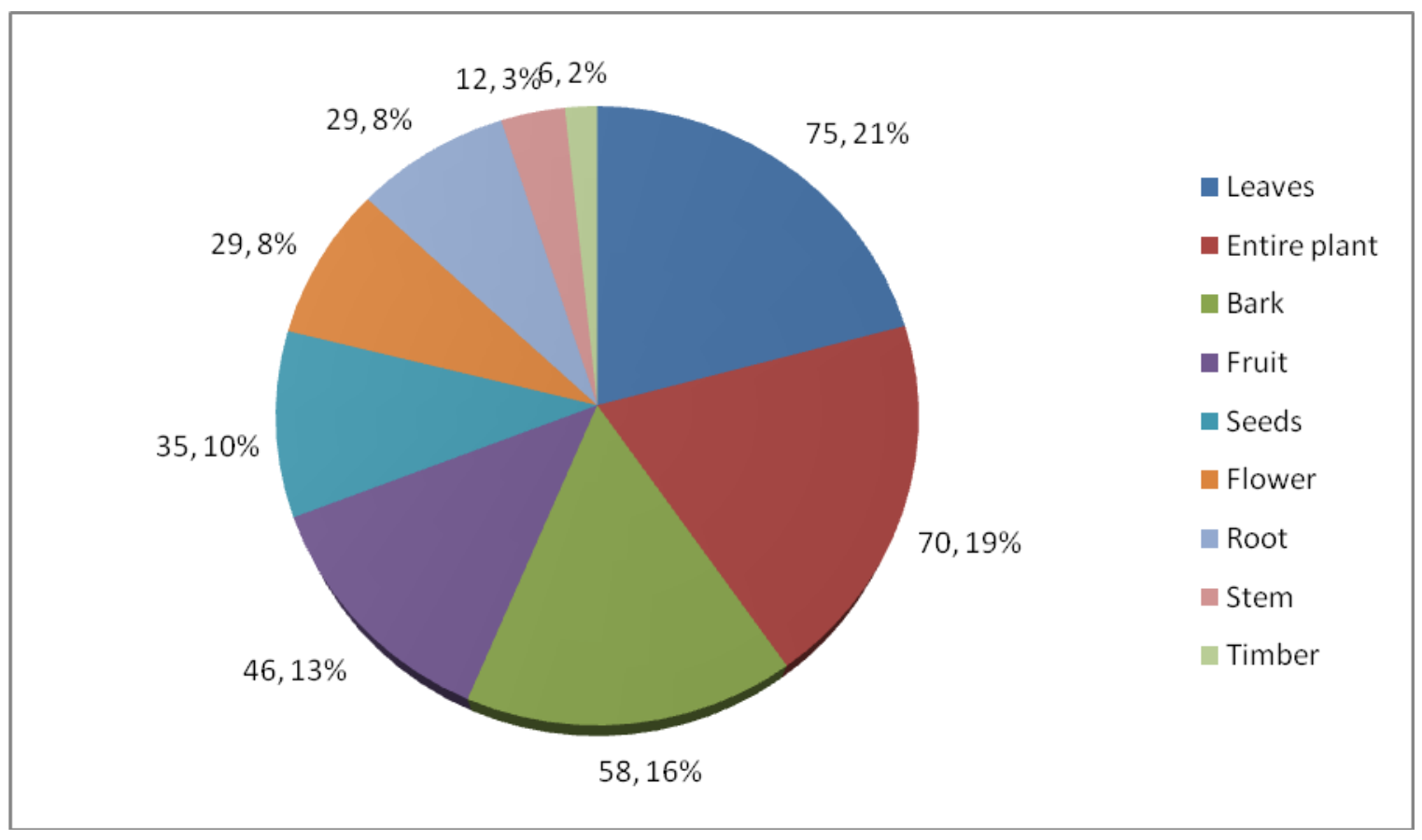

FIGURE 5: Percentage of plant parts used 
South American Journal of Medicine

Special Edition 2016

\section{PLATE 1}

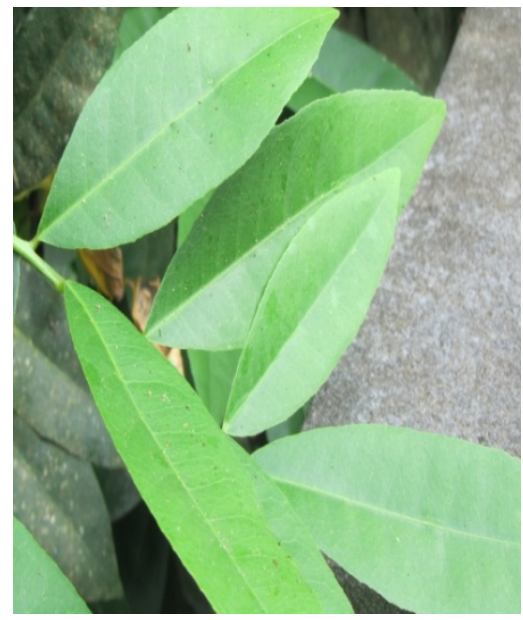

Gycosmis maurihna L

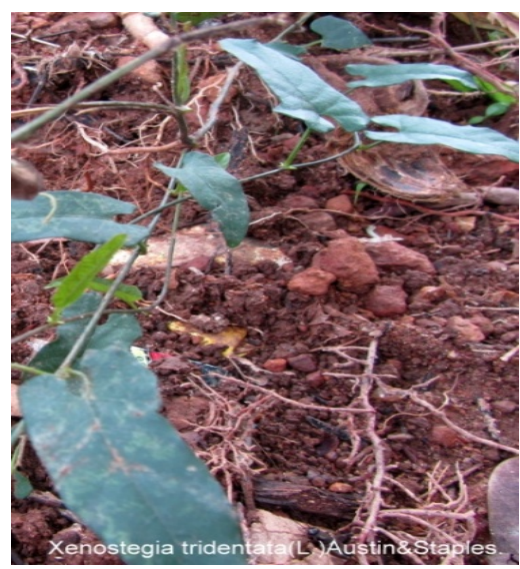

Xenostegia tridentate

(L.)Aushin\&Staples

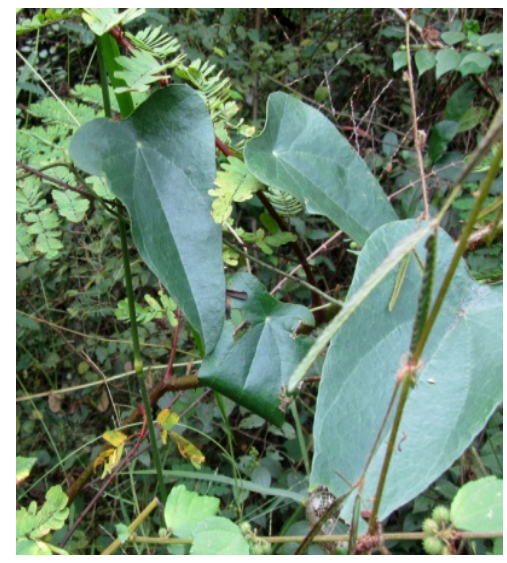

Cyclea peltata

(Lam.)Hookf\&Thomson

Punikkol Grove
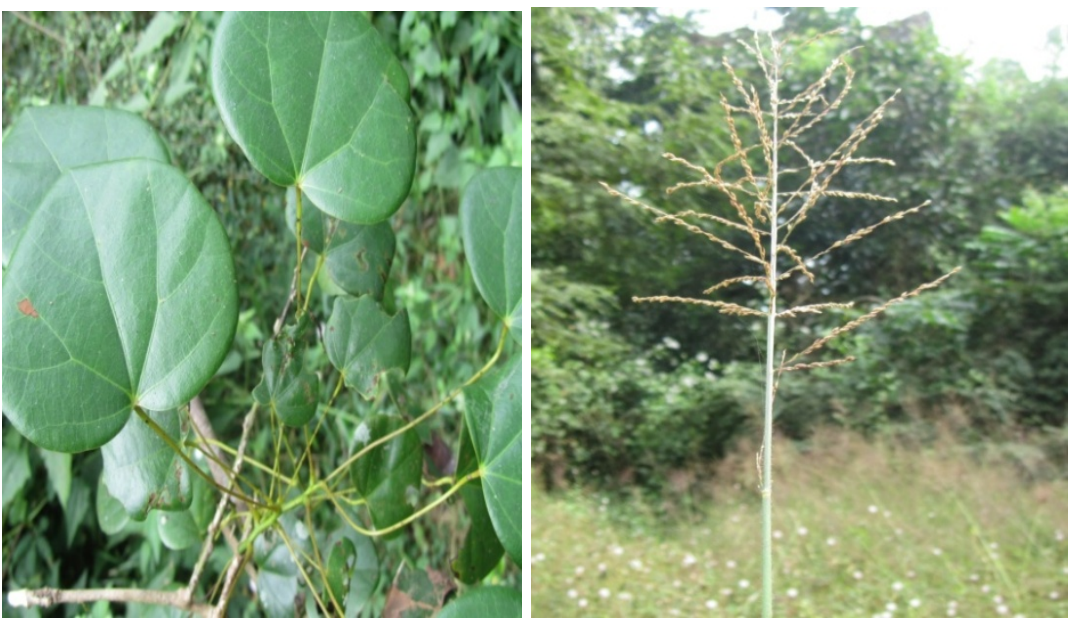

Diplocyclos palmatus Arundinella purpurea

(L.)Jeffrey

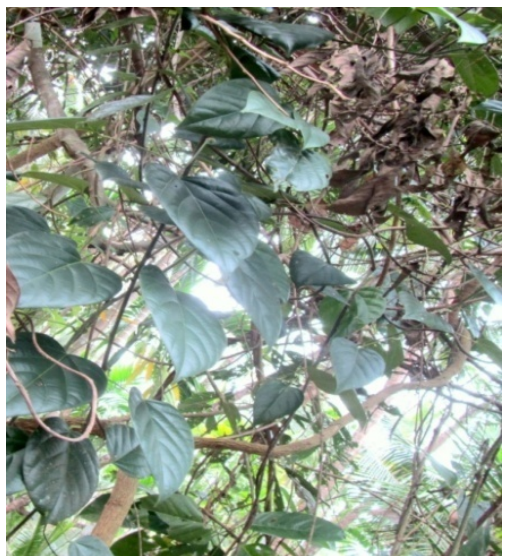

Anamirta cocculus

(L.)Wight \& Arn

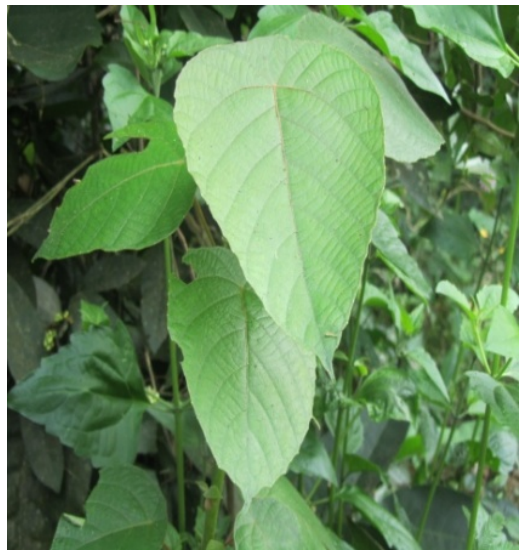

Macaranga peltata

Roxb.Mueller
Hochst.exSteud.

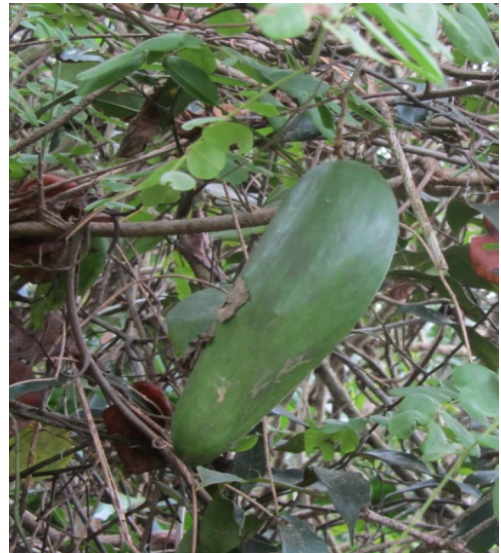

Wattakaka volubilis Stapf.

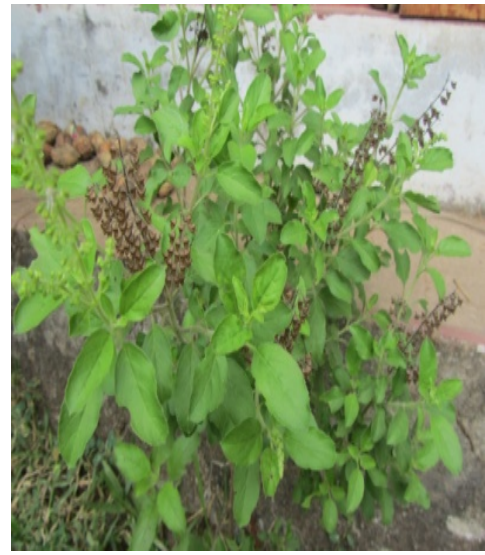

Ocimum tenuiflorum L. 
PLATE 2

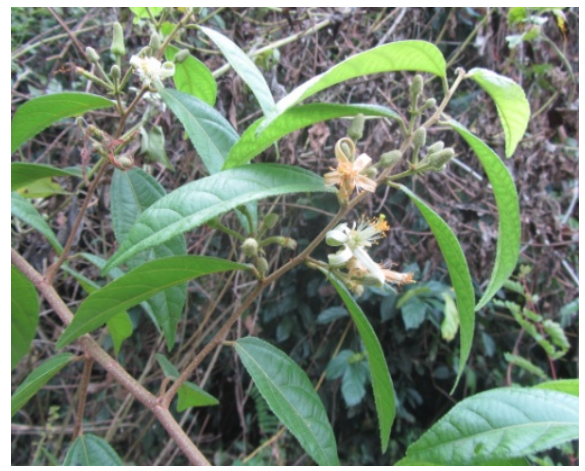

Grewia nervosa Lour.

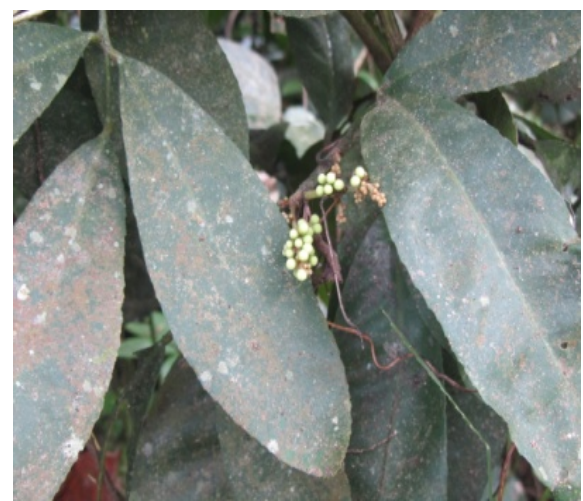

Glycosmis pentaphylla (Retl.)DC.

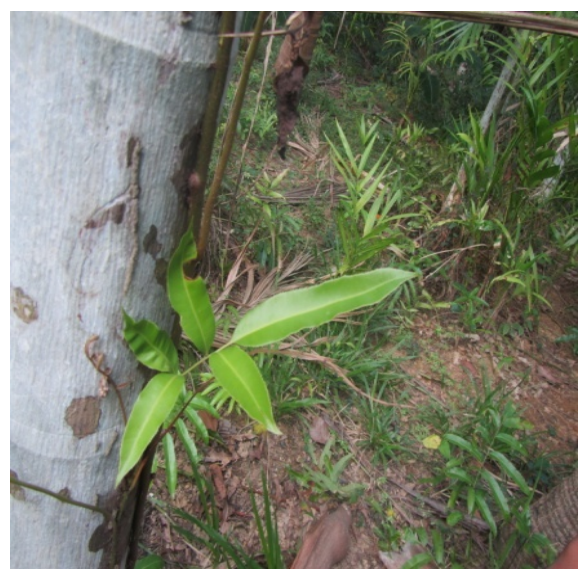

Drynaria quercifolia (L.)DC.ex Wight

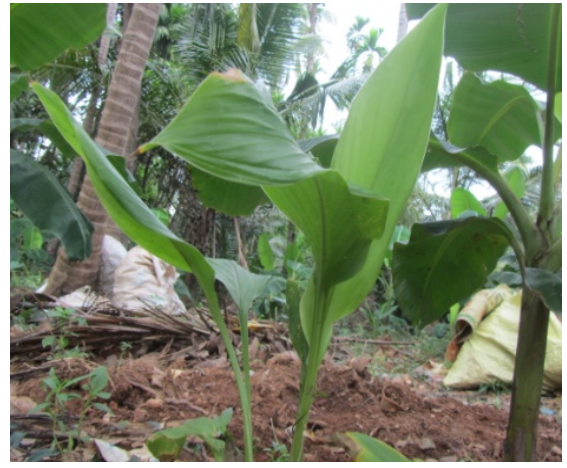

Curcuma aromatica Salisb

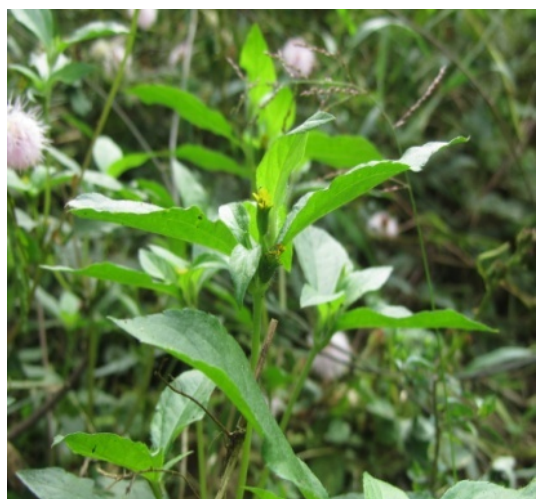

Synedrella nudiflora (L.)Gertn.

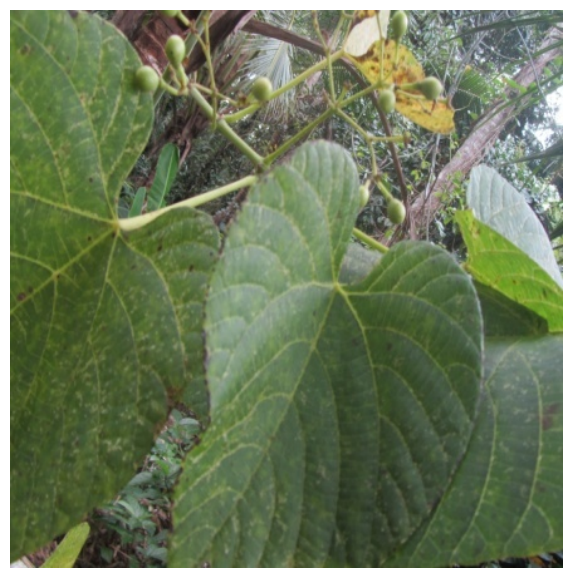

Cosmostigma recemosum(Roxb.)Wight.

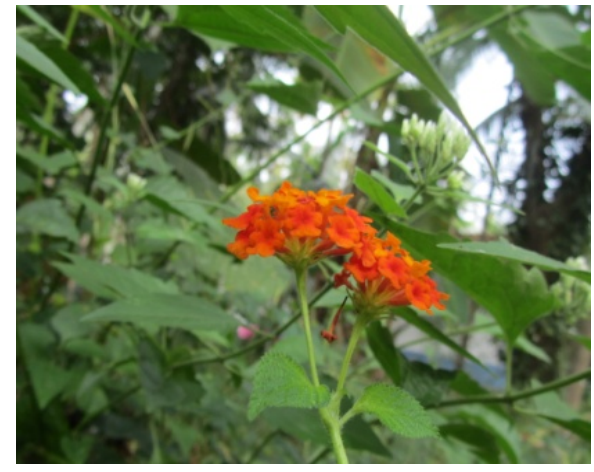

Lanthana camara Linn.

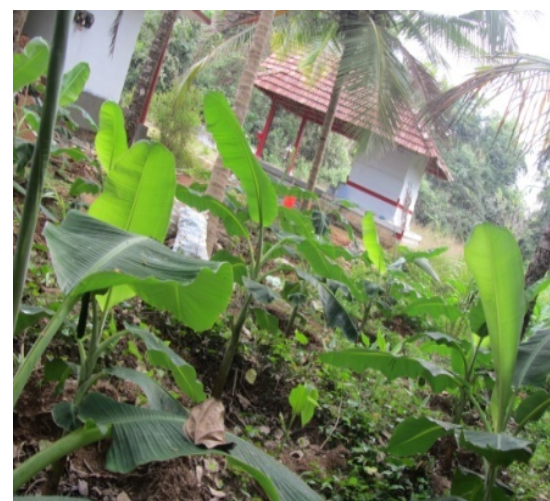

Musa paradisiaca L.

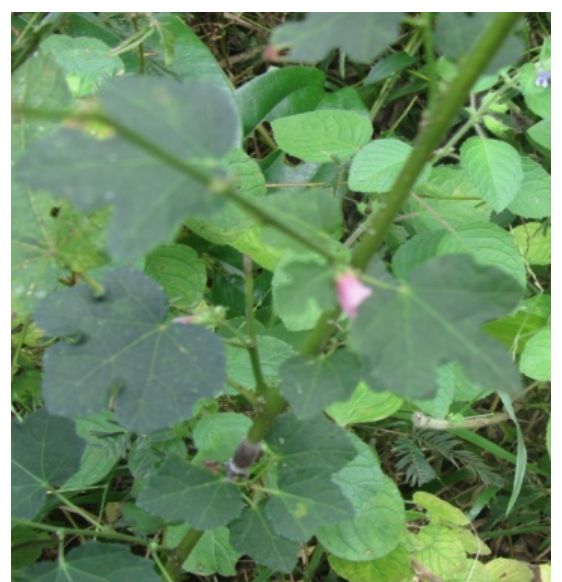

Urena lobata L. 
South American Journal of Medicine

Special Edition 2016

\section{PLATE 3}

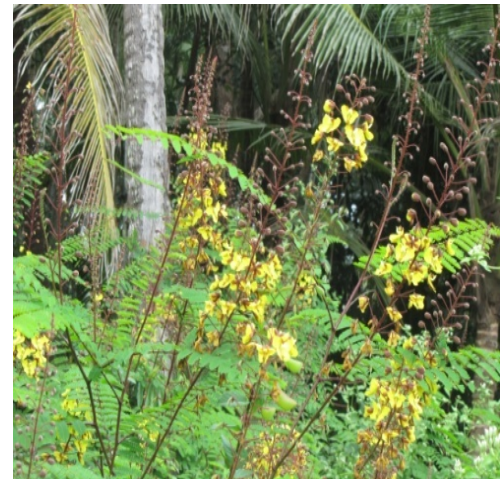

Caesalpinia mimosoides Lam

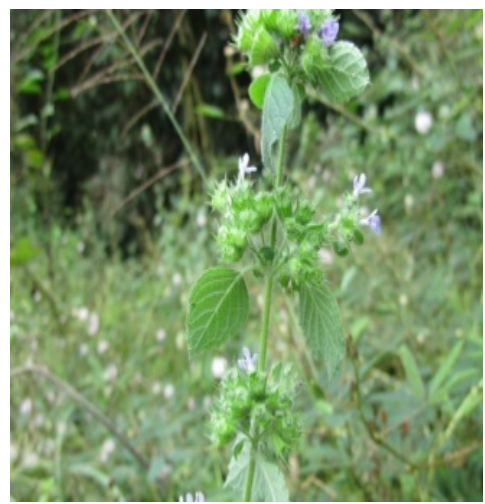

Hyptis suaveolens (L.)

Poit.

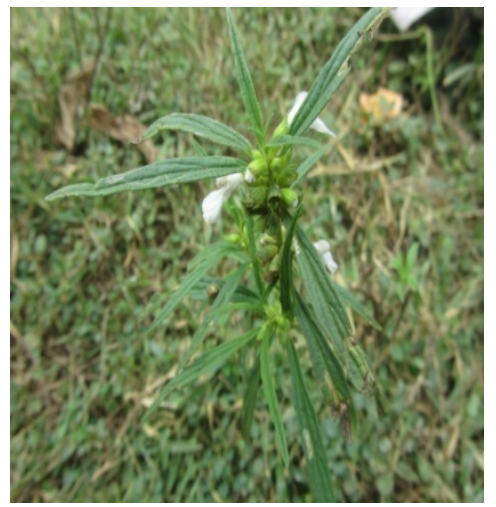

Leucas lavandulifolia L.

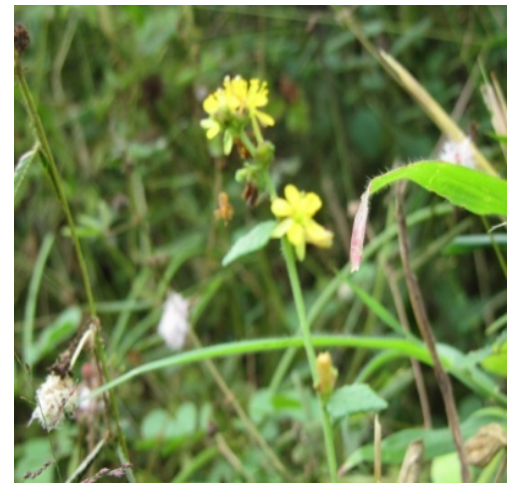

Triemfetta rhomboidea Lam

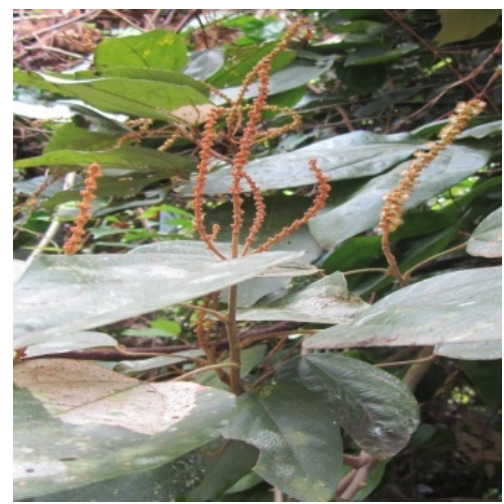
Mallotus philippensis (Lam.) Mull-Arg

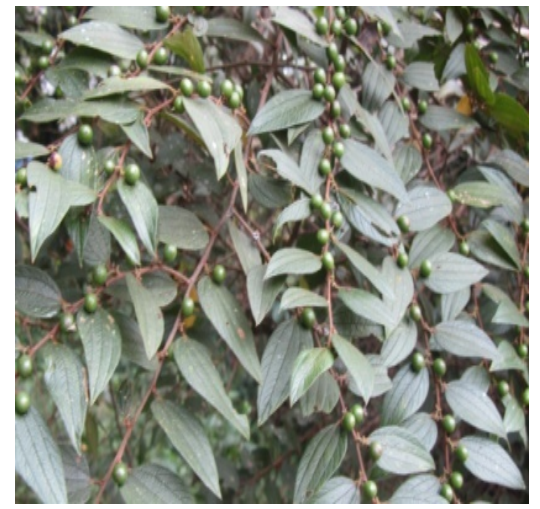

Ziziphus oenopolia (L.) Mill.

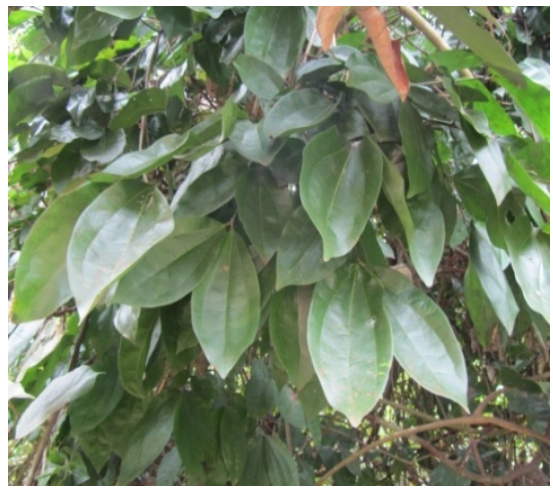

Strycnos nux-vomica Linn

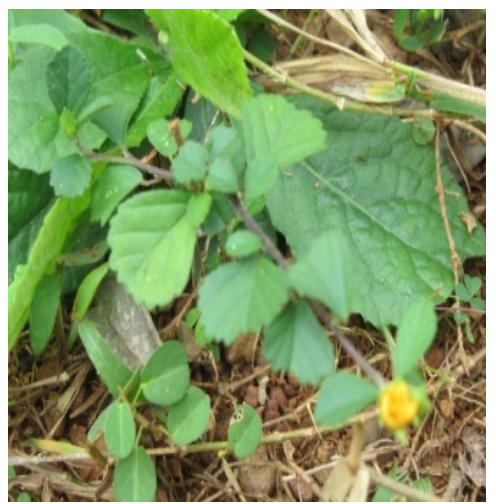
Sida alnifolia $\mathrm{L}$.

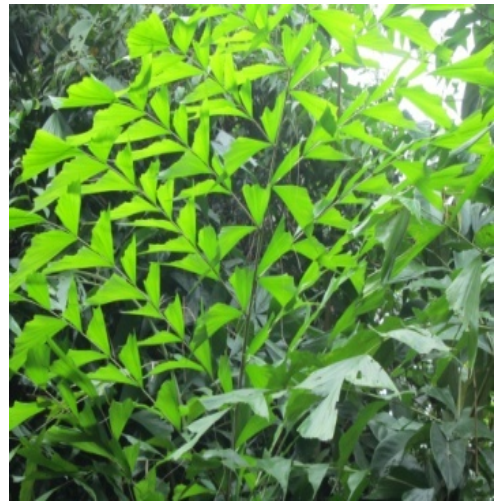

Caryota urens L. 
PLATE 4

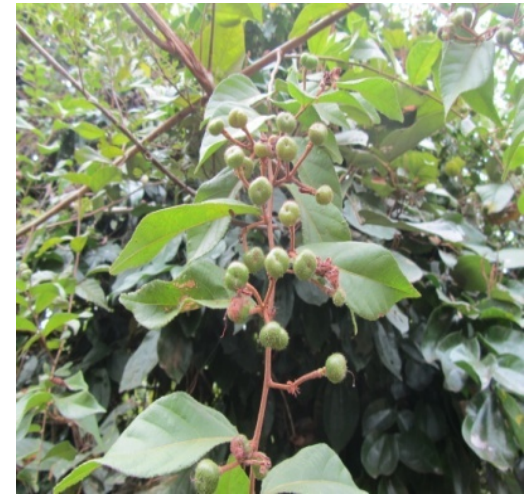

Grewia hirsute Vah.

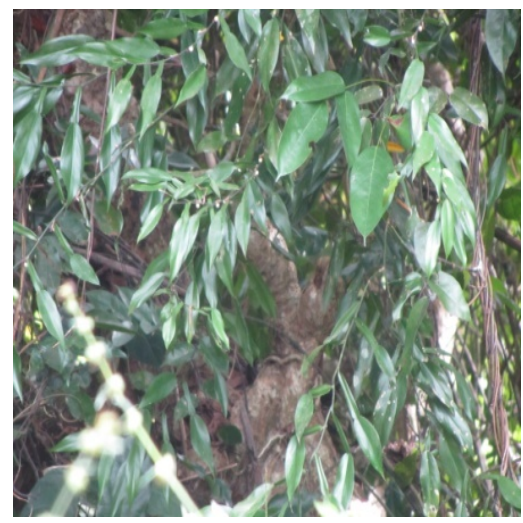

Pothos scandens L.

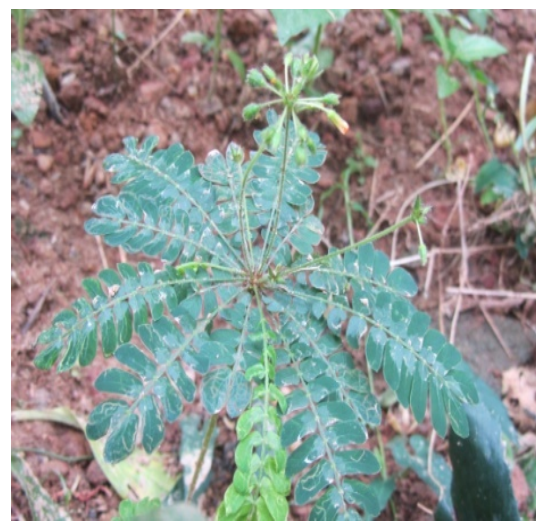

Biophytum sensitivum (1.)DC. Glirisedia sepium (Jacq.)Kunth ex walp.

(L.)R.Br.

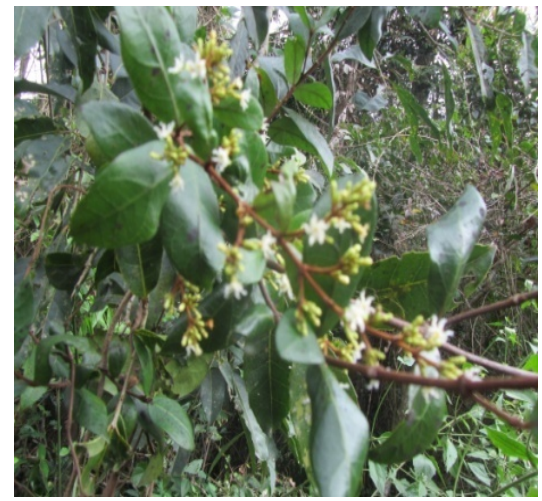

Ichnocarpus fruitescens

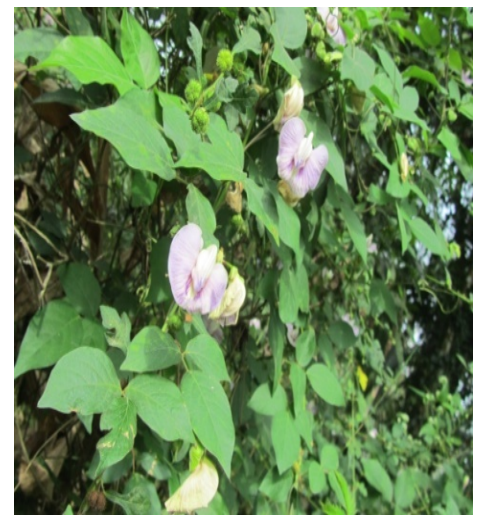

Centrosoma molle Benth.
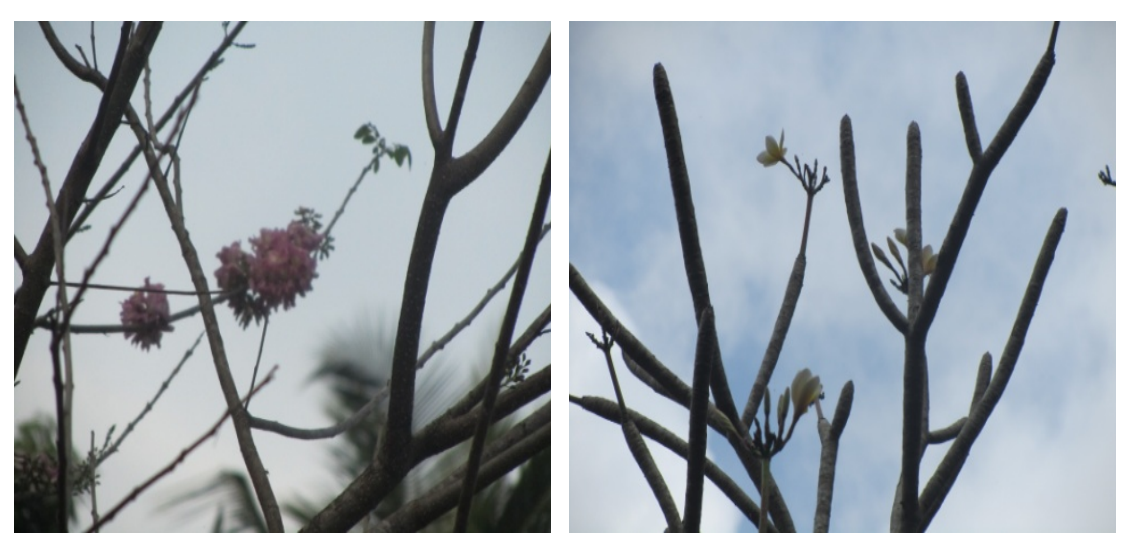

Plumeria rubra Poir.

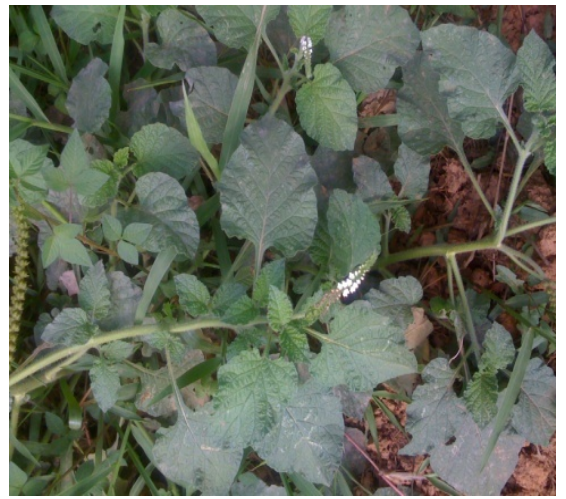

Heliotropium indicum $\mathrm{L}$.

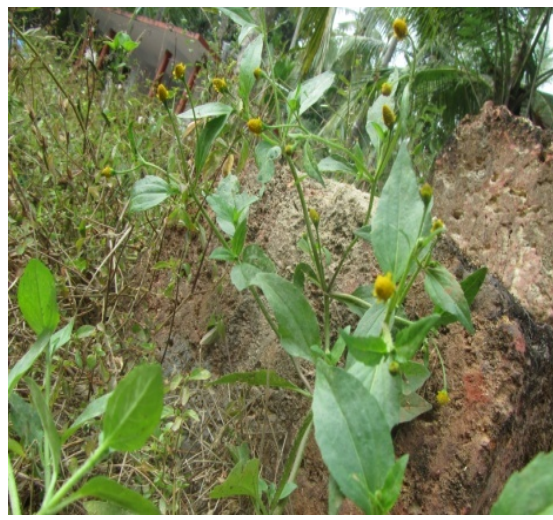

Acmella paniculata (Kunth.)Cass. 
South American Journal of Medicine

Special Edition 2016

\section{PLATE 5}

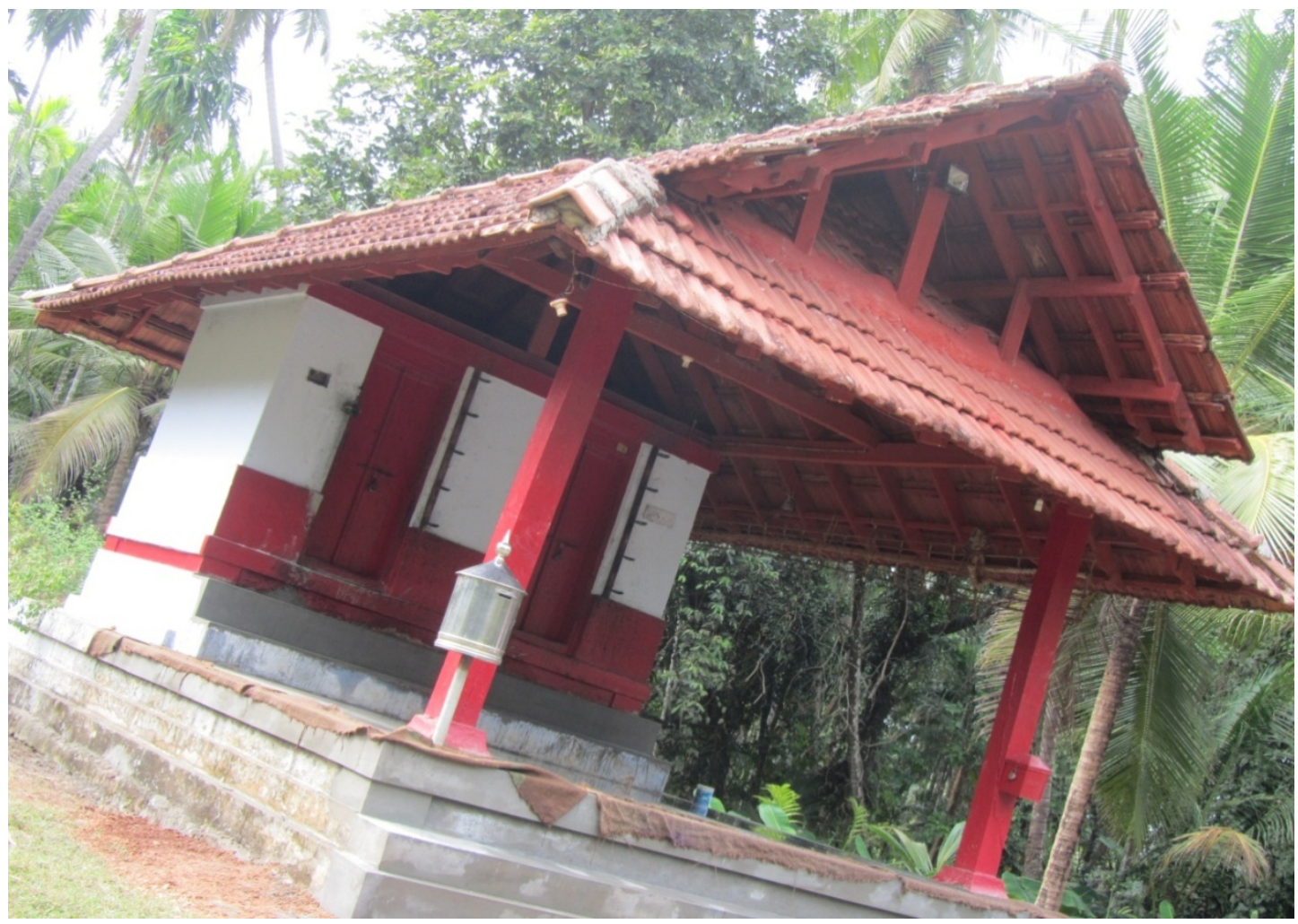

a) Front view of the Grove

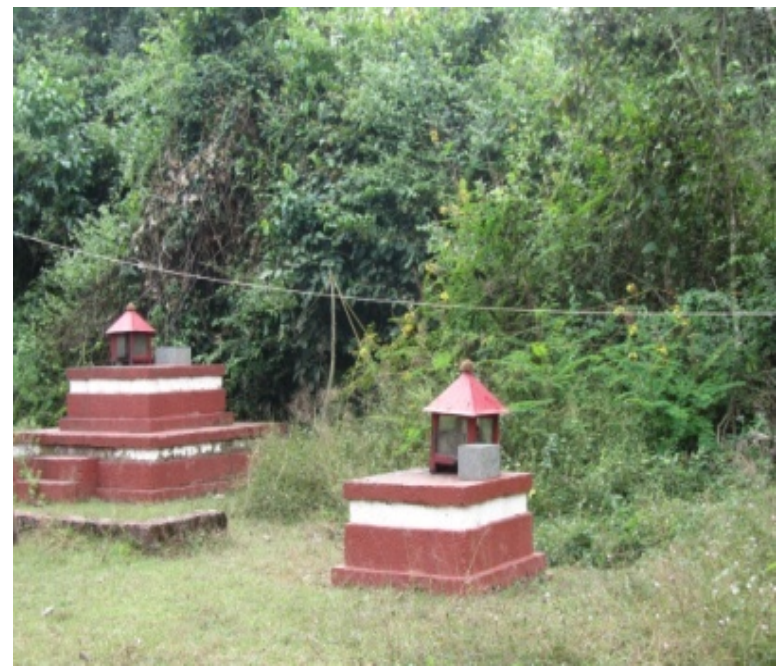

b) Devasthanam

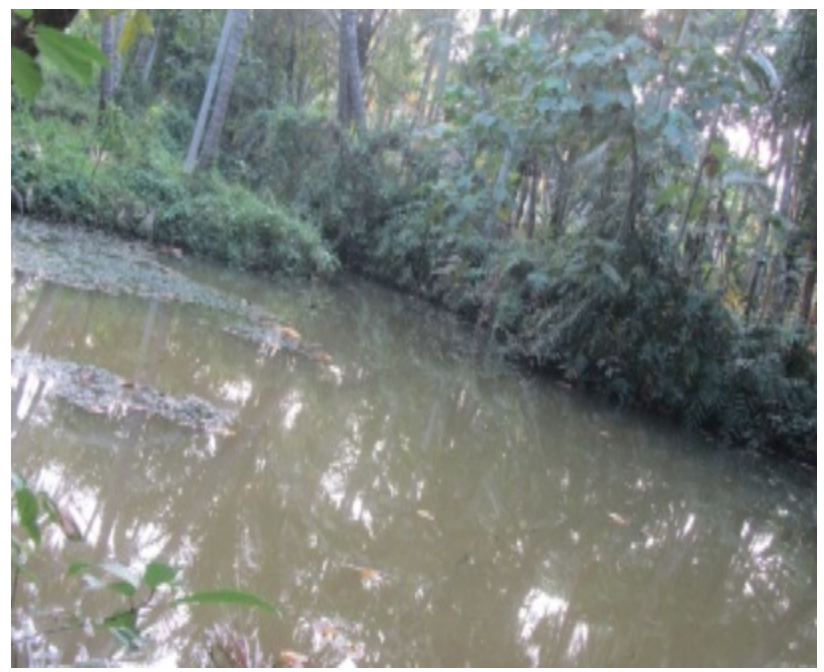

c) Pond behind the Grove 
PLATE 6

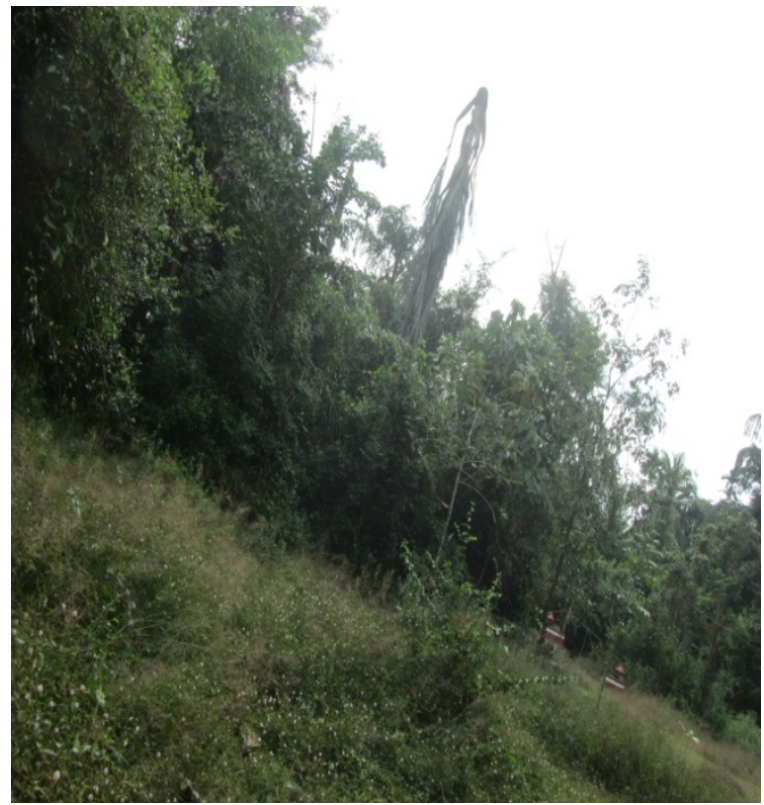

a) Plants are protected

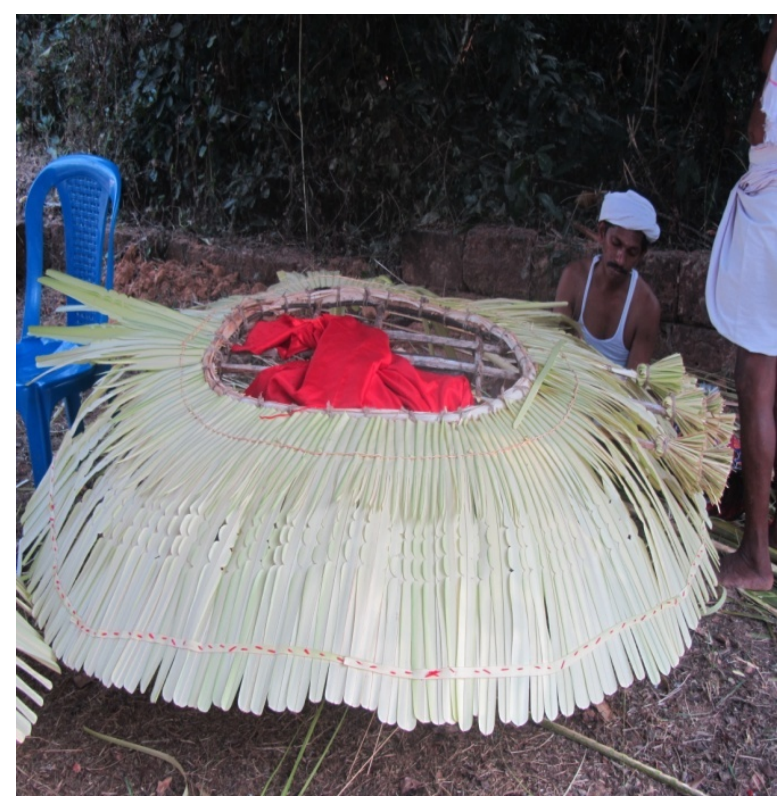

c) Prepairing thirumudi

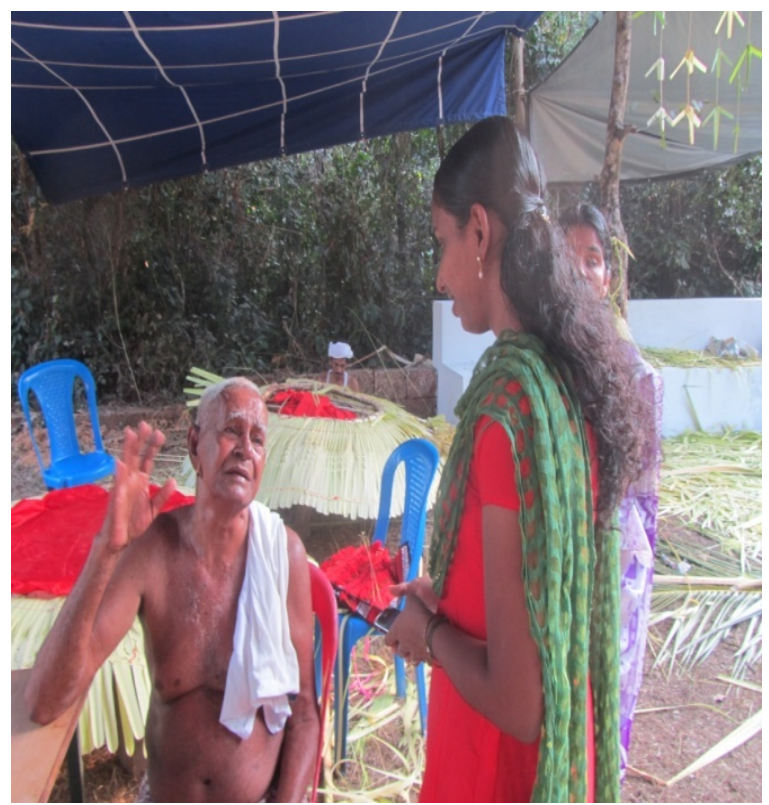

b) Data collection

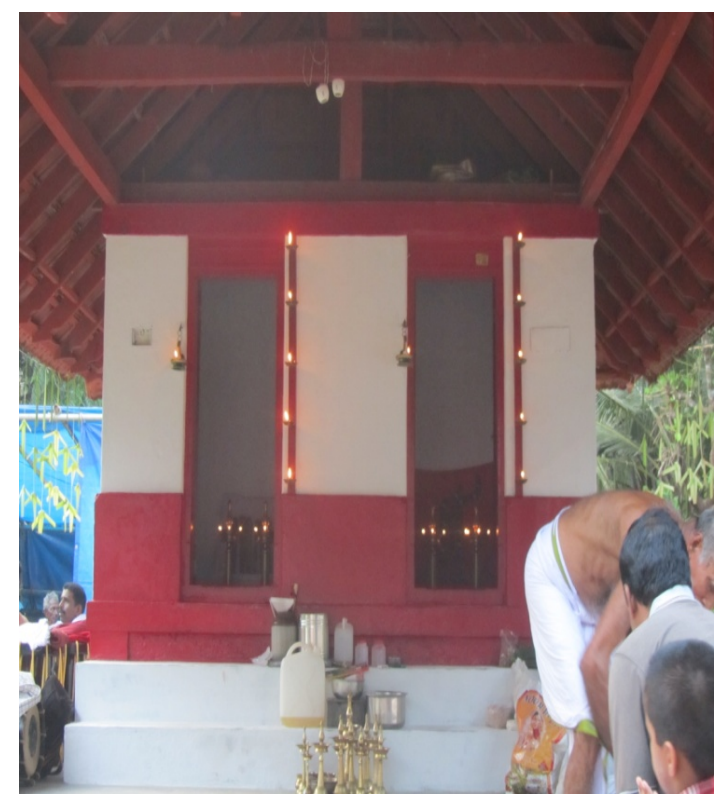

d) Front view of (the temple in) Punikkol kaavu 
South American Journal of Medicine

Special Edition 2016

\section{PLATE 7}
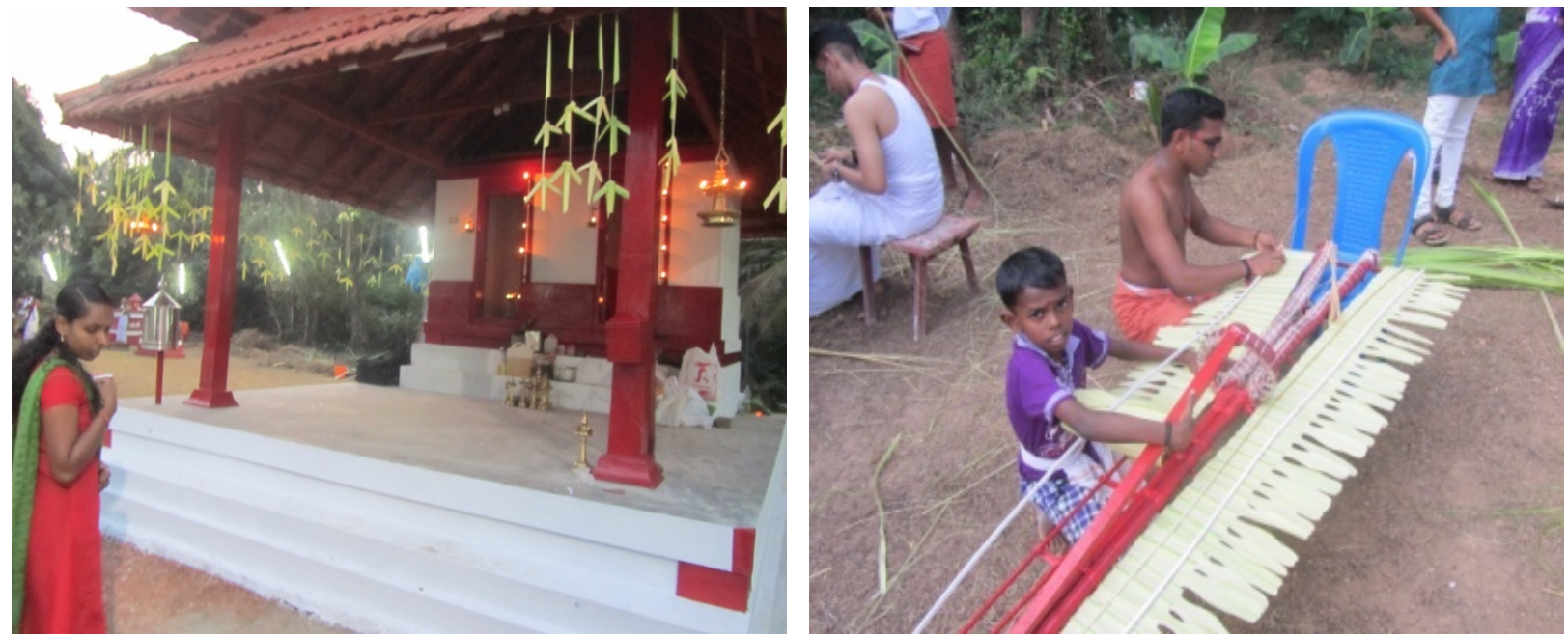

a) Grove during festival

b) Prepairing thirumudi of Gulikan

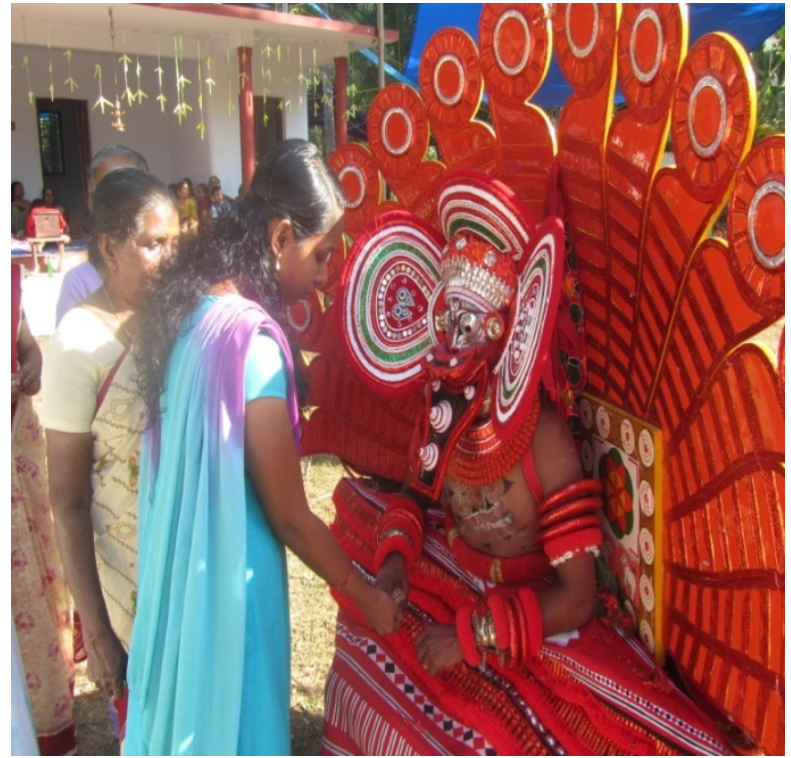

c) Saasthappan theyyam

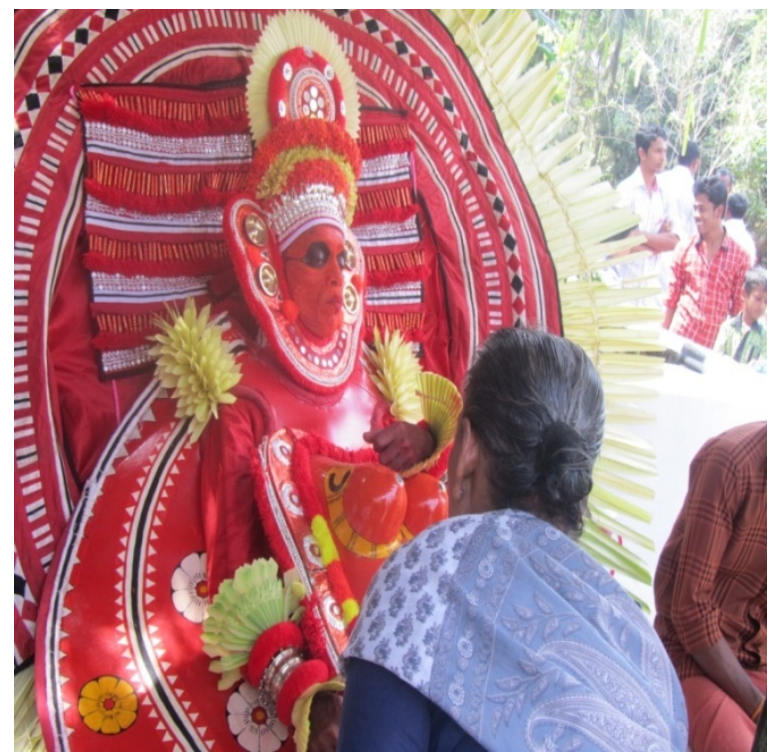

d) Rakthachamundi 


\section{PLATE 8}

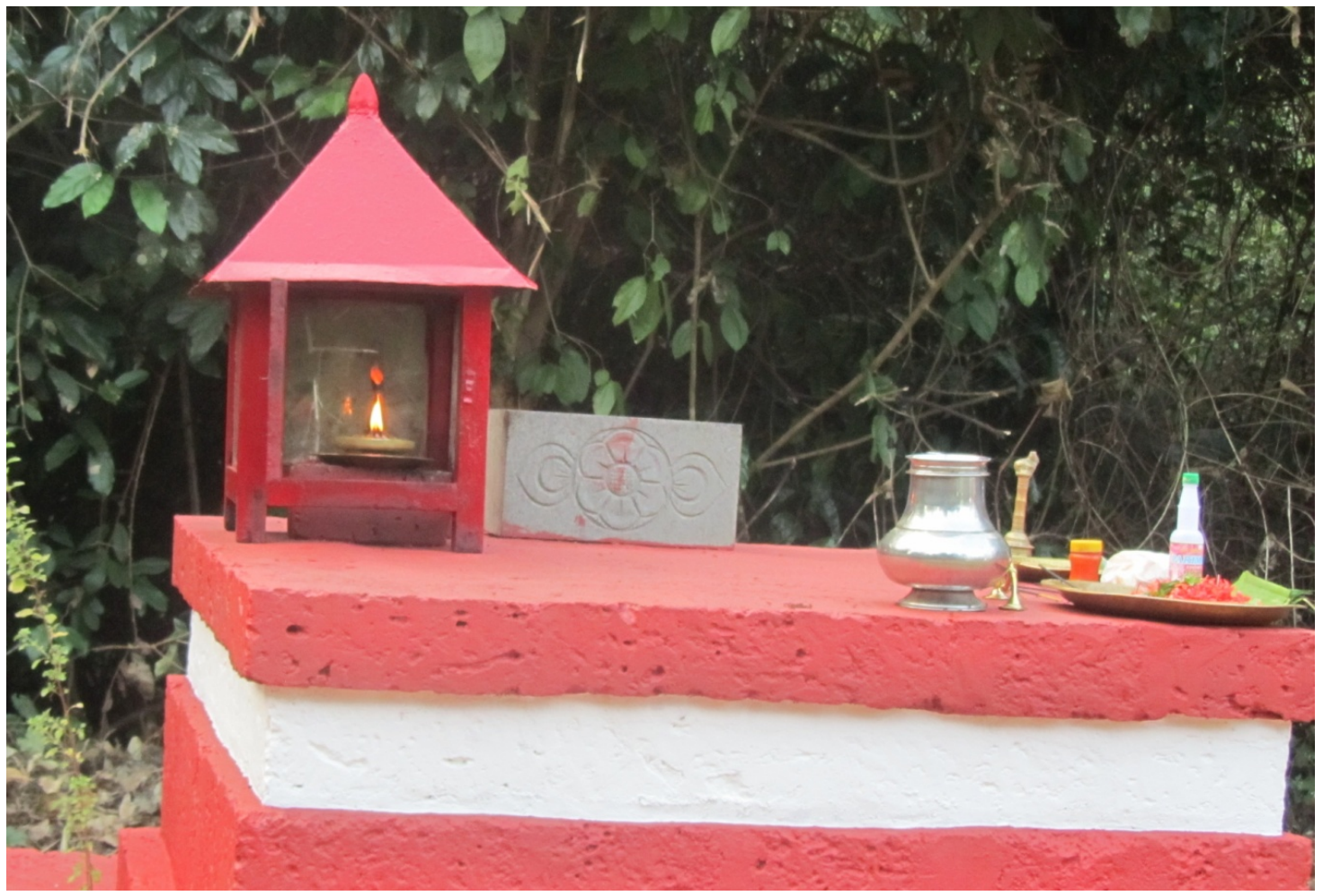

a) Use of different flowers for worshipping God(Pooya vaykkal)

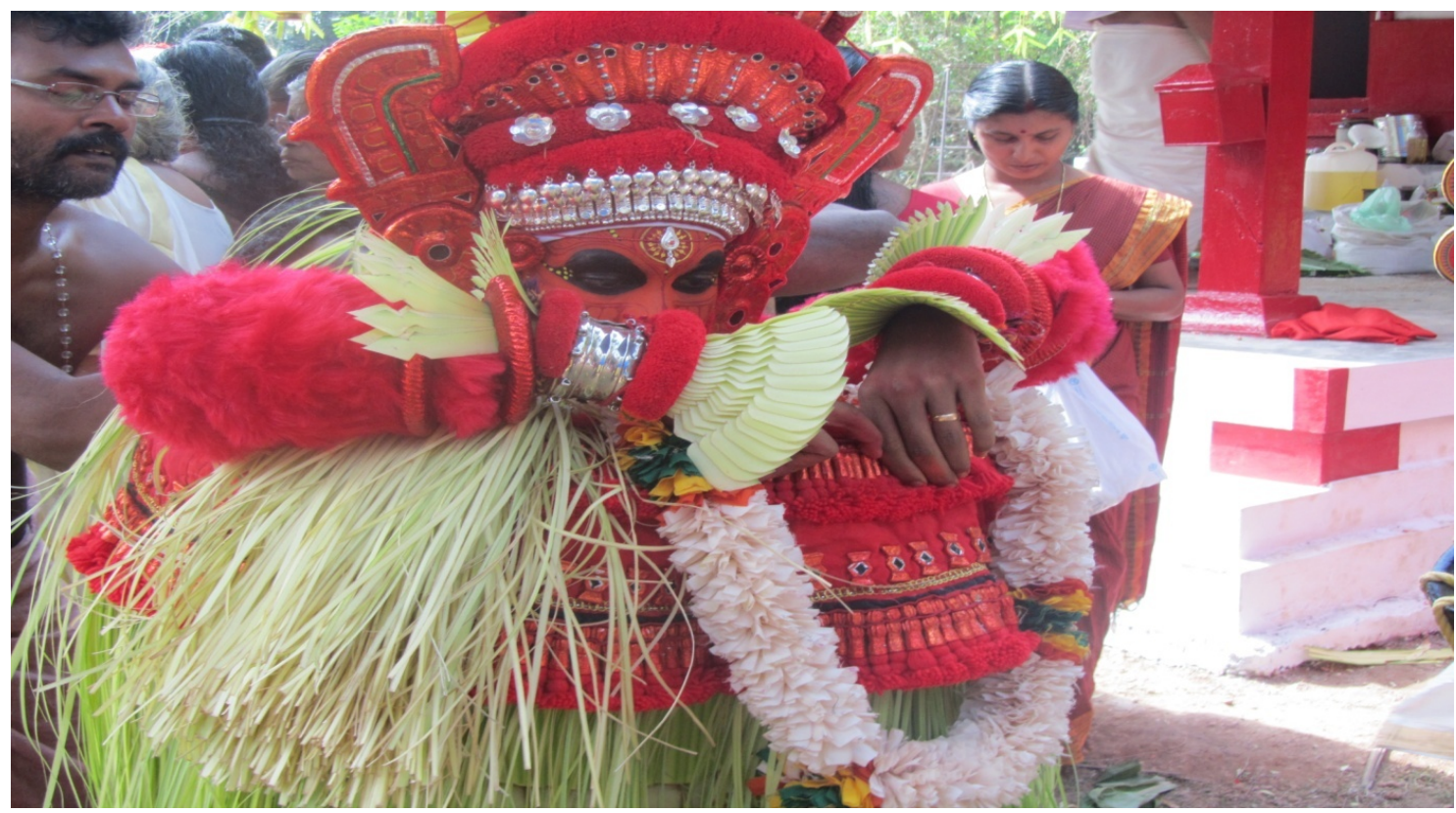

b) Use of tender leaves of coconut for making the ornaments of God.

PLATE 9 
South American Journal of Medicine

Special Edition 2016

\section{CHIRAKKAKAVU}
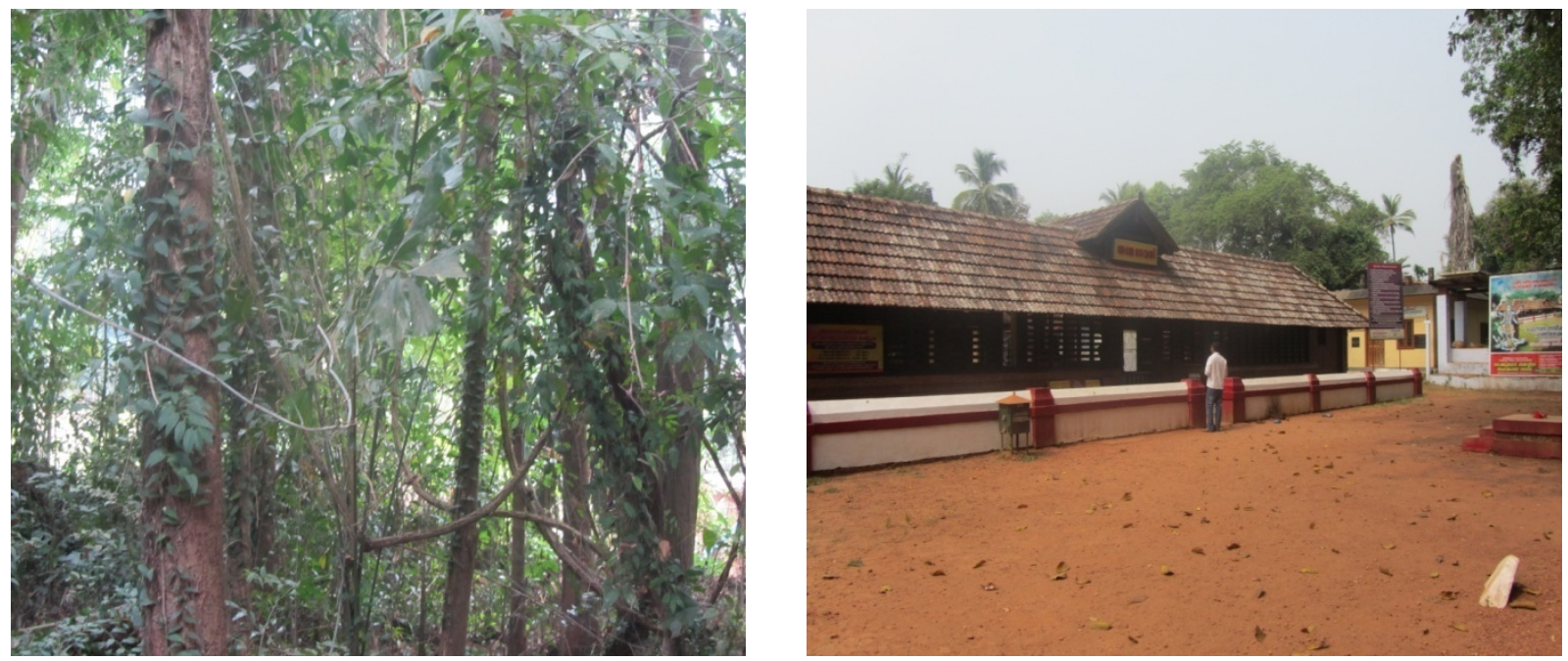

a. Overview of the Grove b.

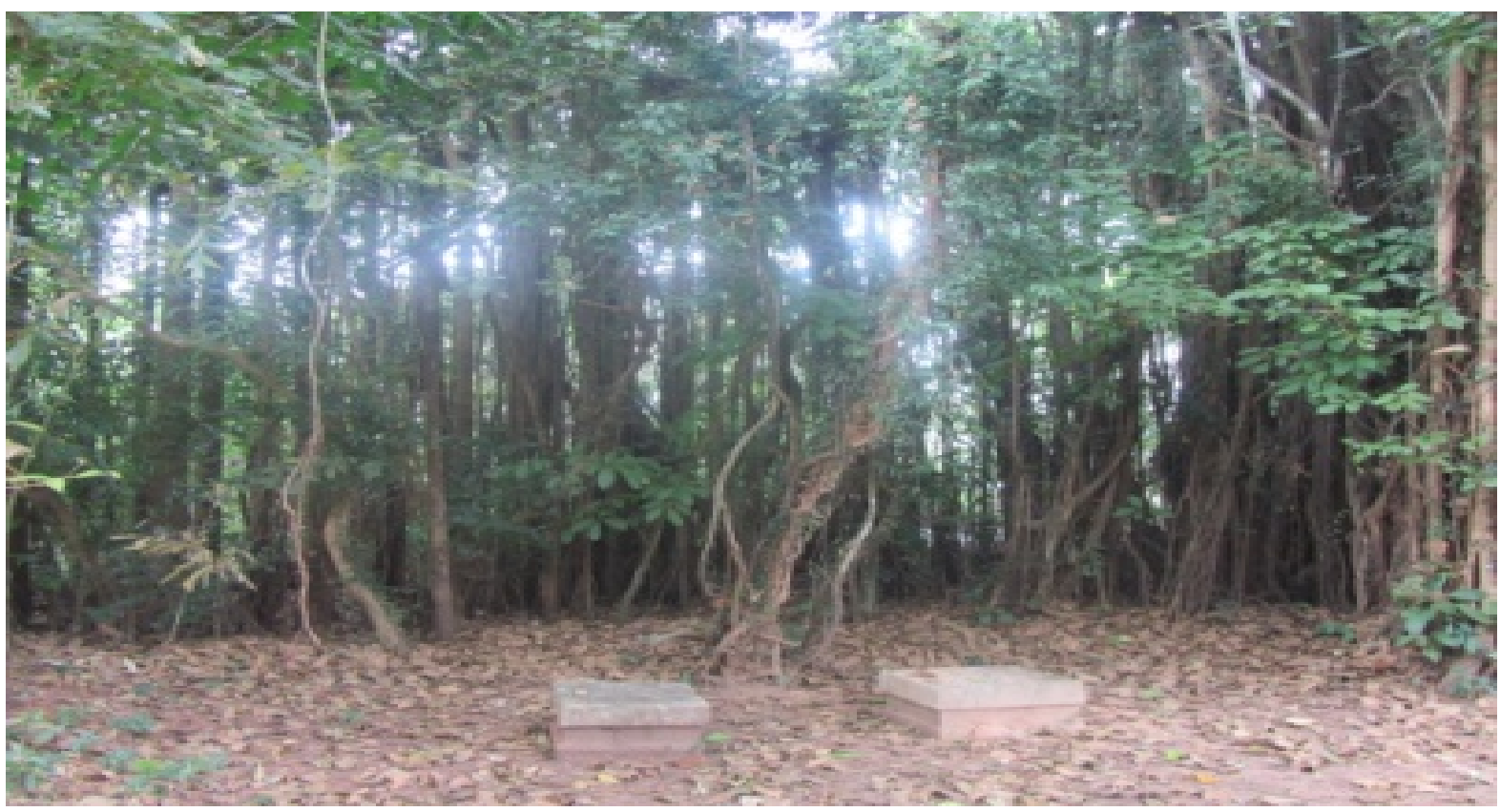

c) Ficus trees are protected 
PLATE 10

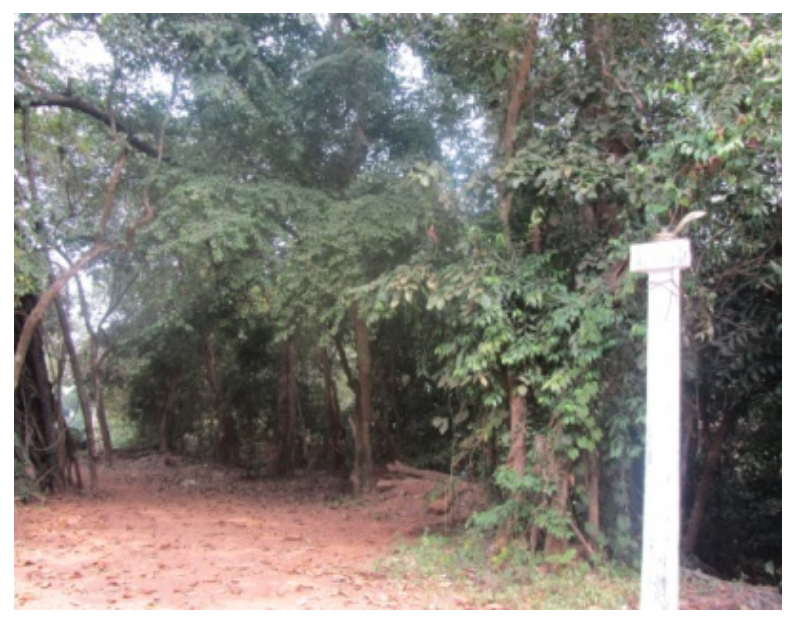

a) Plants in front of the Grove

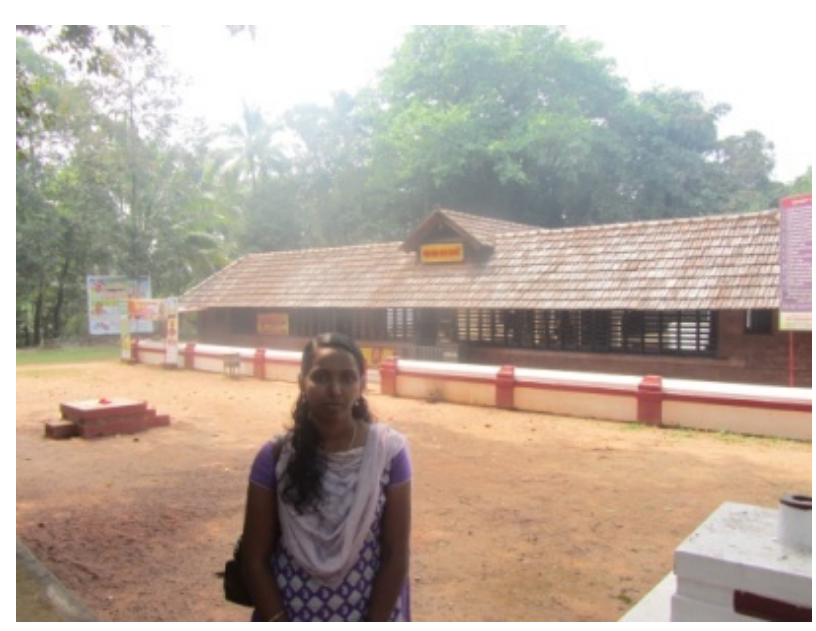

b) Grove from one side

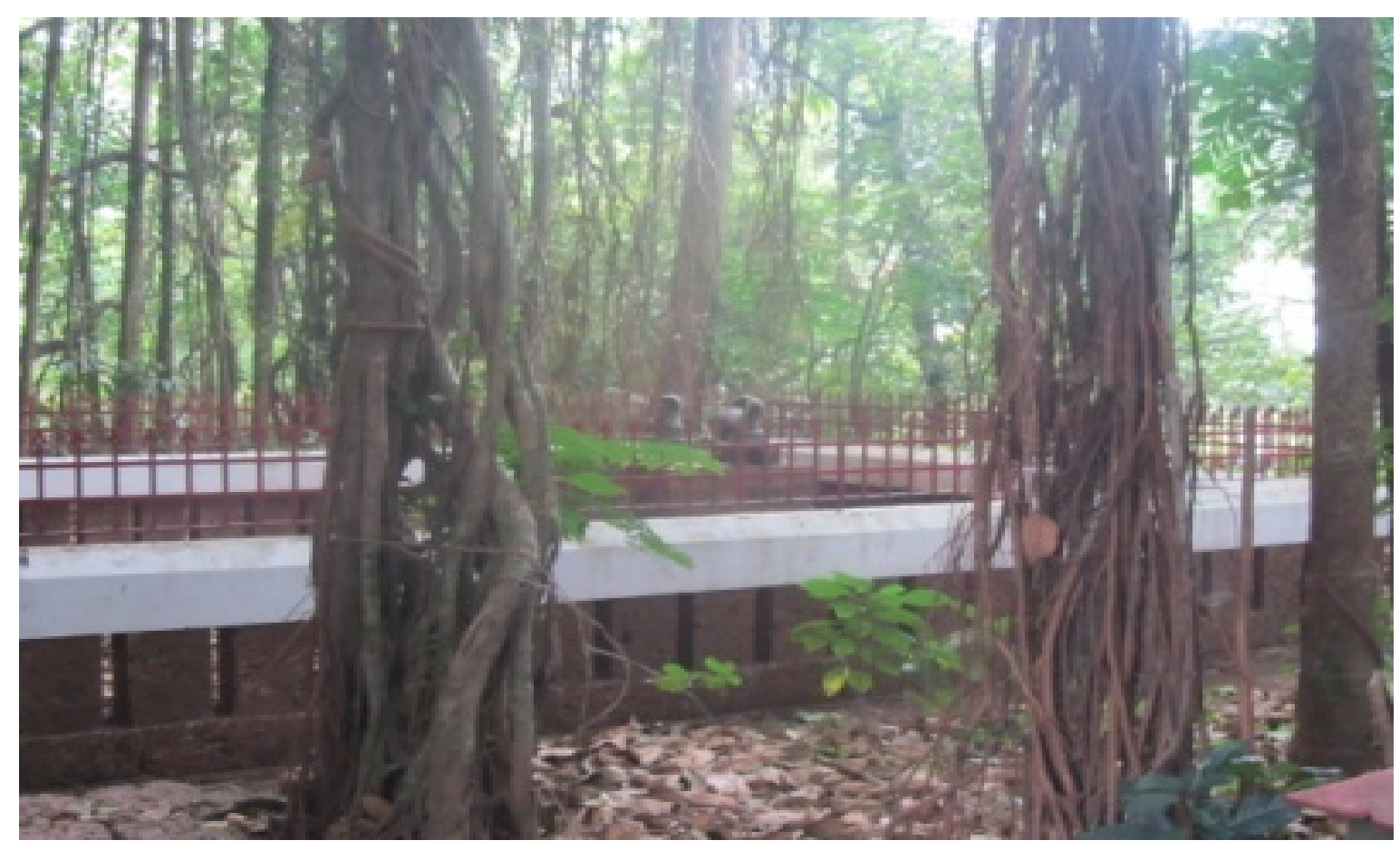

c) Sarppakavu 
South American Journal of Medicine

Special Edition 2016

\section{PLATE 11: PLANTS SEEN IN CHIRAKKAKAVU}

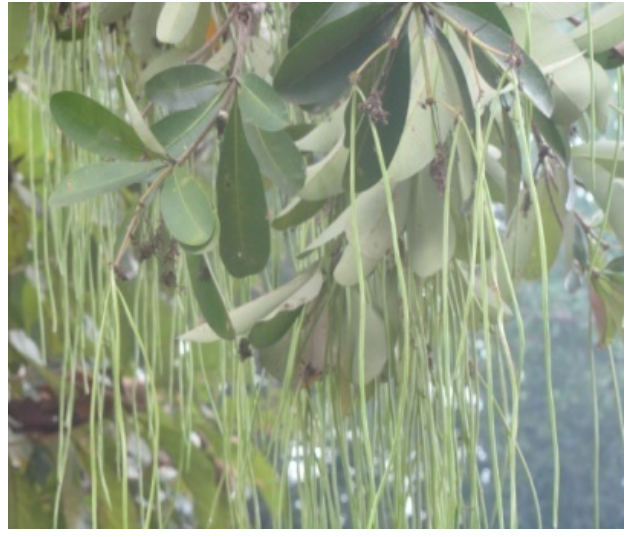

Alstonia scolaris R.Br.

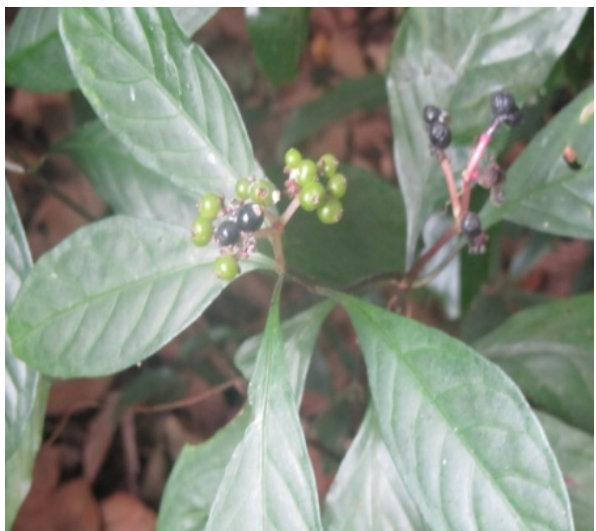

Charsalia curviflora (Wll.ex

Kurz.)Thvaiten

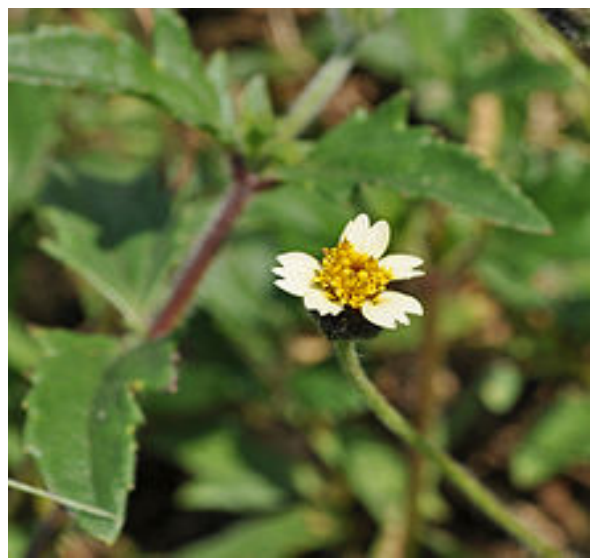

Tridax procumbance $\mathrm{L}$.

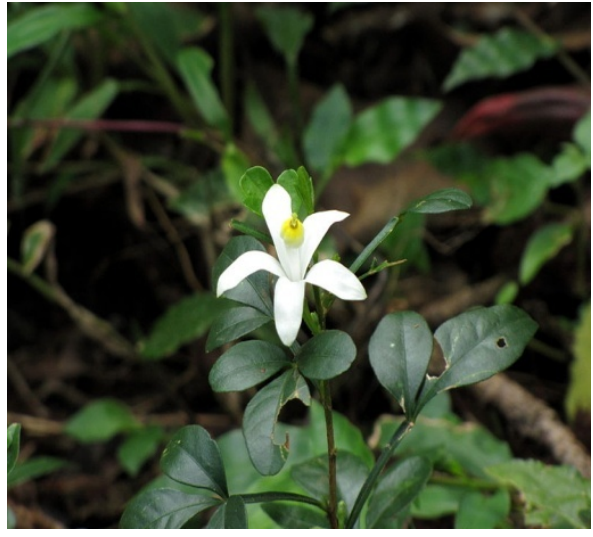

Naregamia alata $\mathrm{W} \& \mathrm{~A}$.

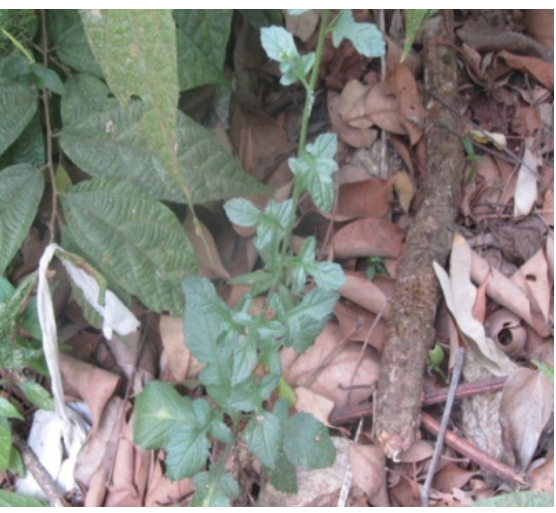

Emilia sonchifolia (L.)DC.EX

Wight.

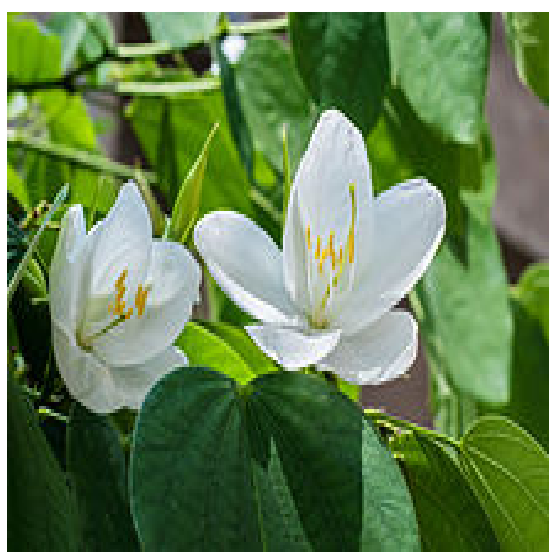

Bauhinia acuminata $\mathrm{L}$.

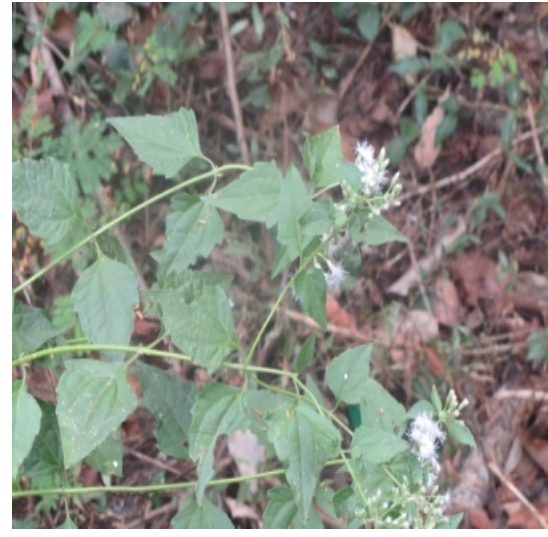

Chromolaena odorata

(L.)King \& H.E.Robins.

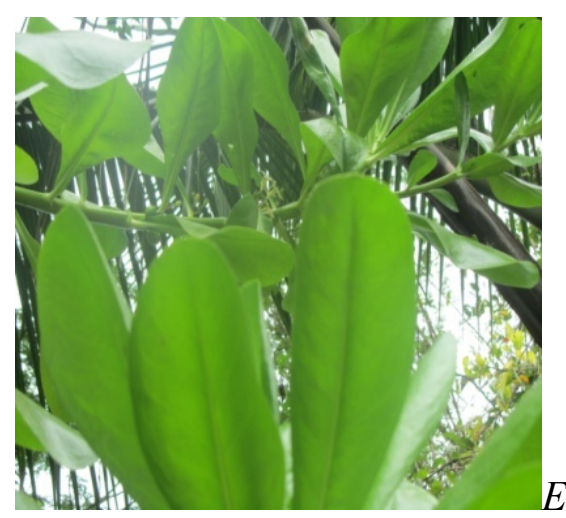

laeocarpus sphaerius Roxb.

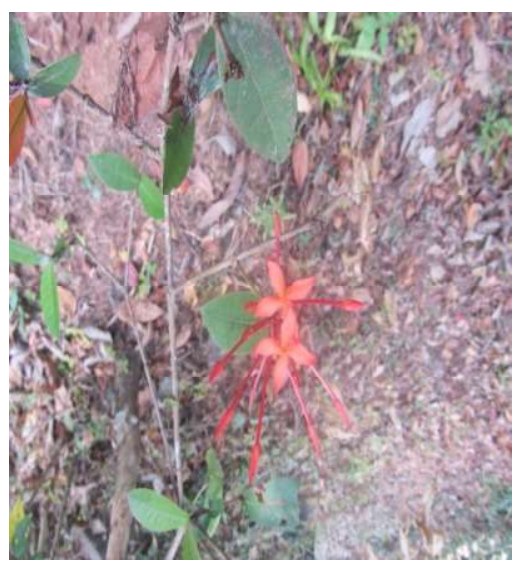

Ixora coccinia $\mathrm{L}$. 
PLATE 12: Plants in Chirakkakvu

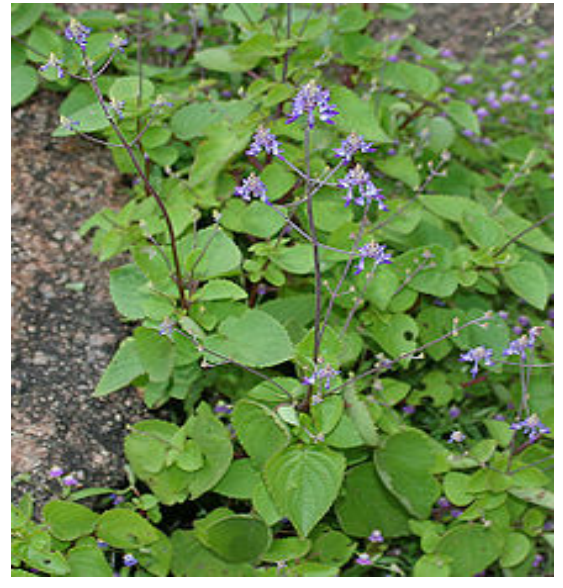

Anisochilus carnosus

(L.f.)Wall.ex Benth.

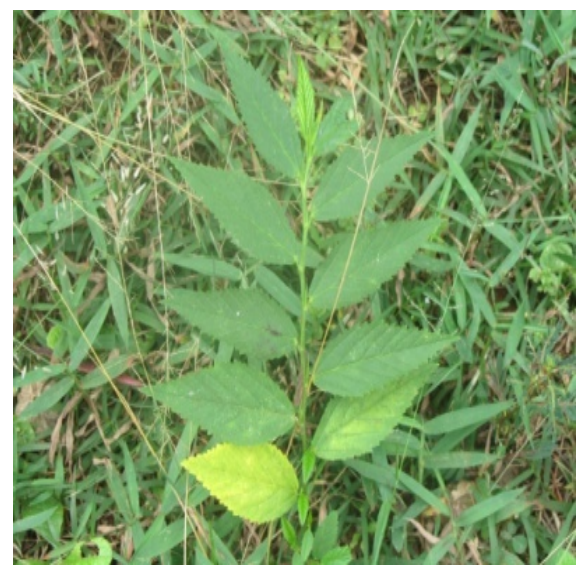

Sida acuta Burm.f.

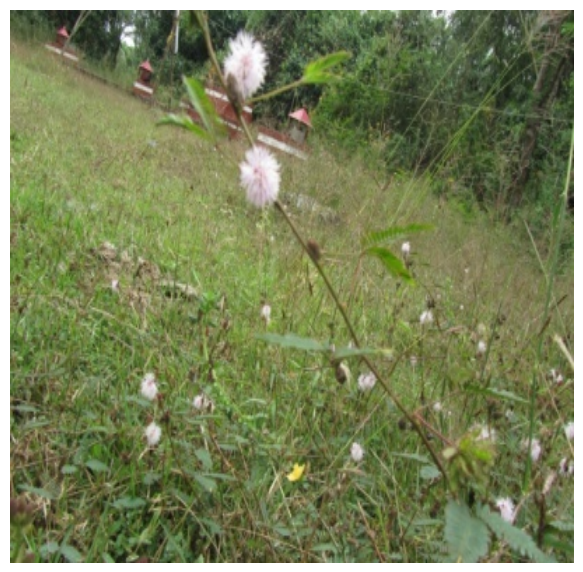

Mimosa pudica L.

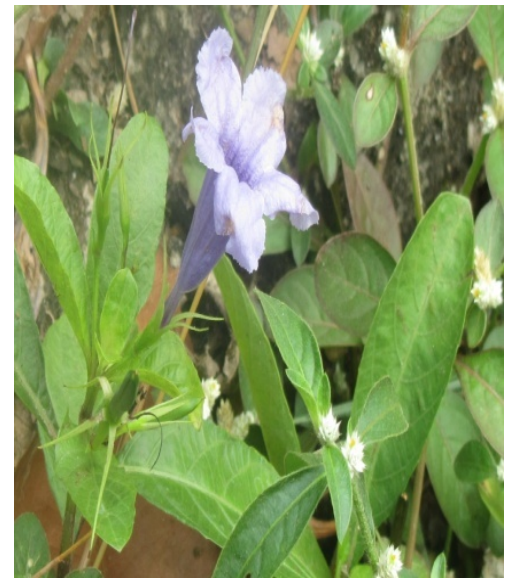

Ruellia tuberose L.

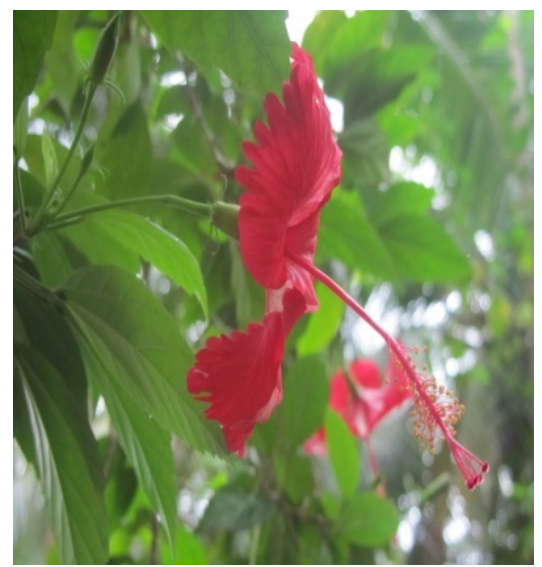

Hibiscus rosacinensis L.

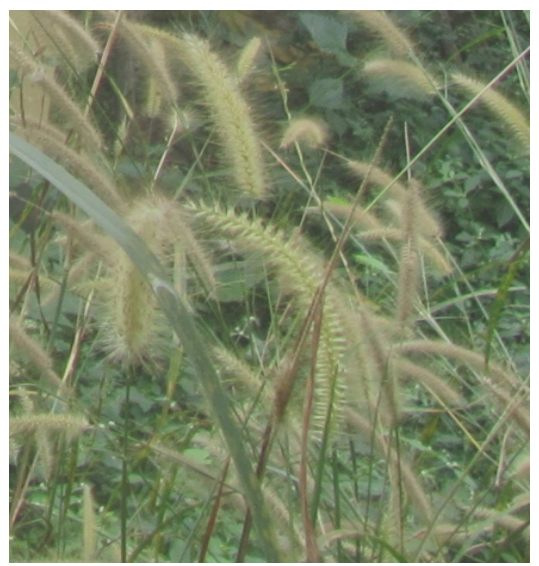

Setaria parviflora L.

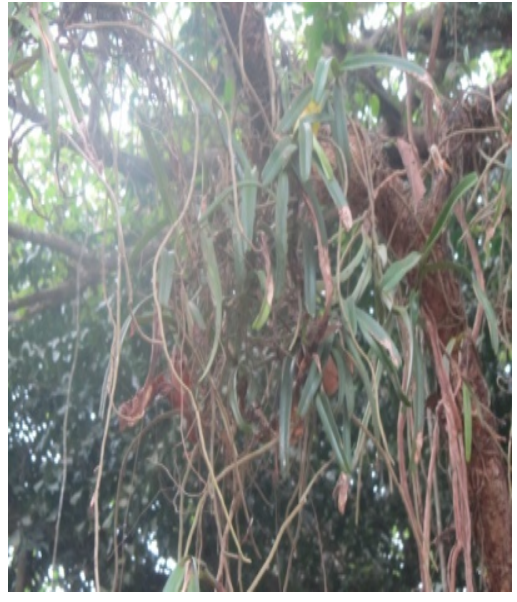

Vanda sp.

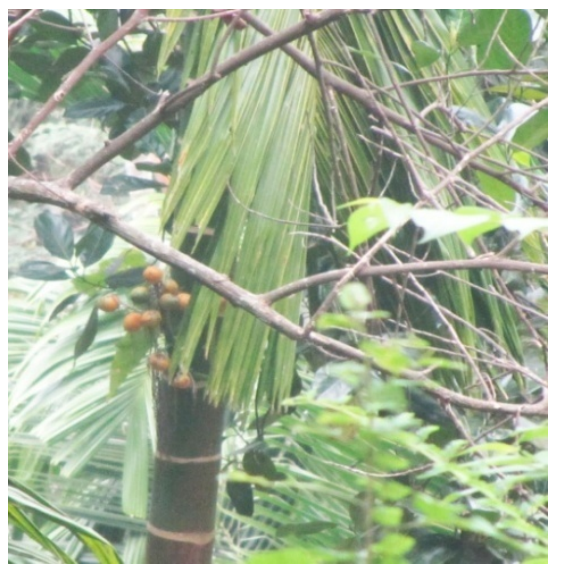

Areca catechu L.

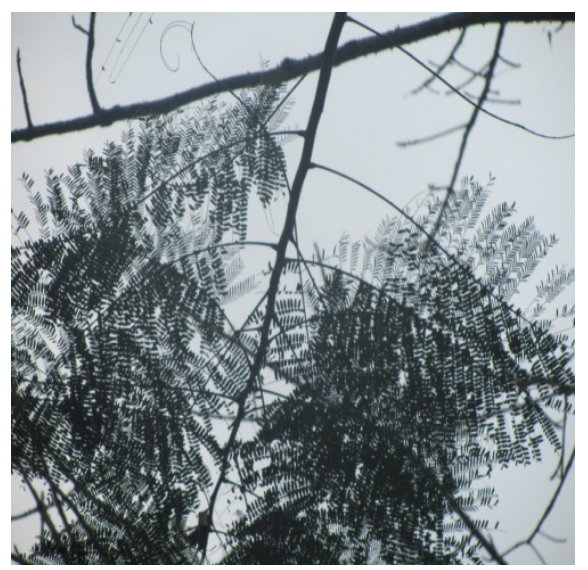

Adenanthera pavonina L. 
South American Journal of Medicine

Special Edition 2016

PLATE 13: SOME TREES SEEN IN CHIRAKKAKAVU

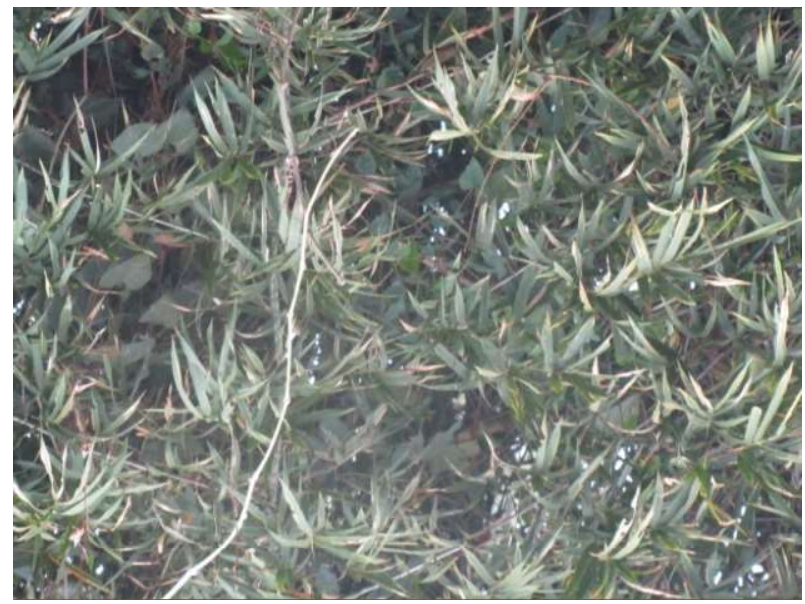

Caryota urens L.

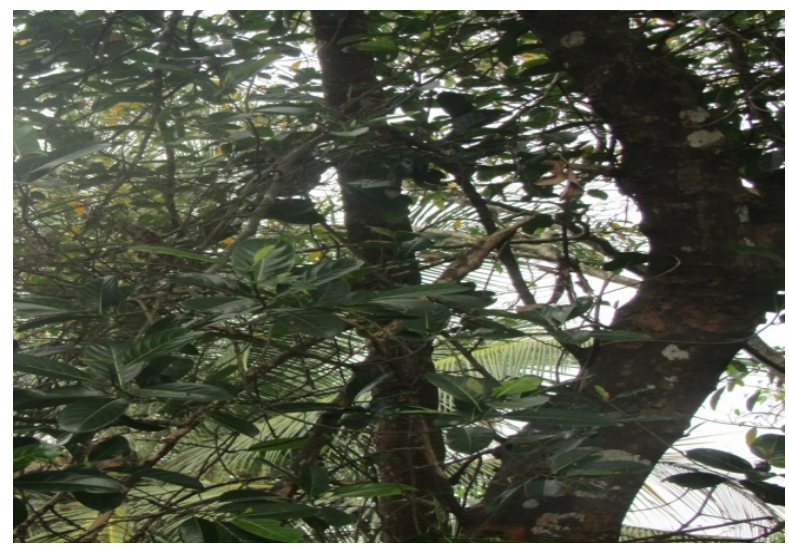

Artocarpus heterophyllus Lam.

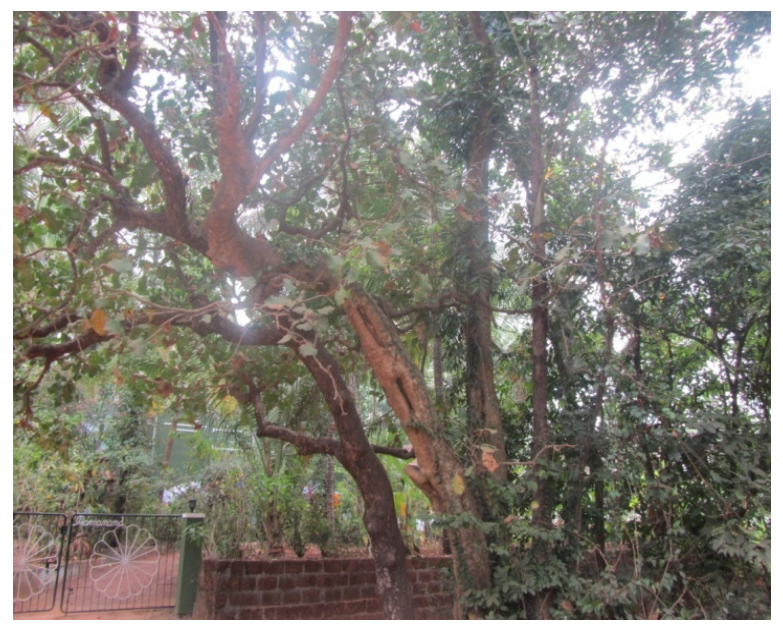

Careya arborea Roxb.

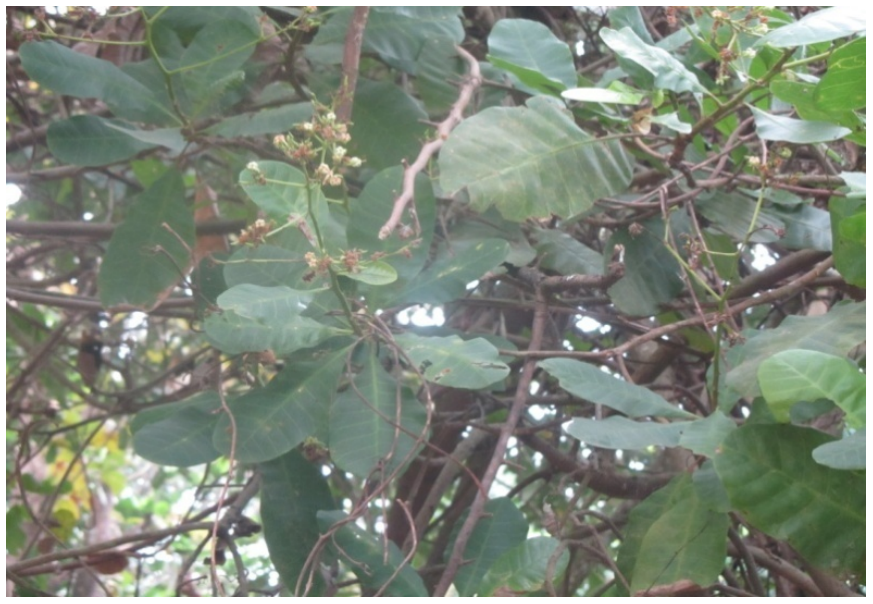

Anacardium occidentale L.

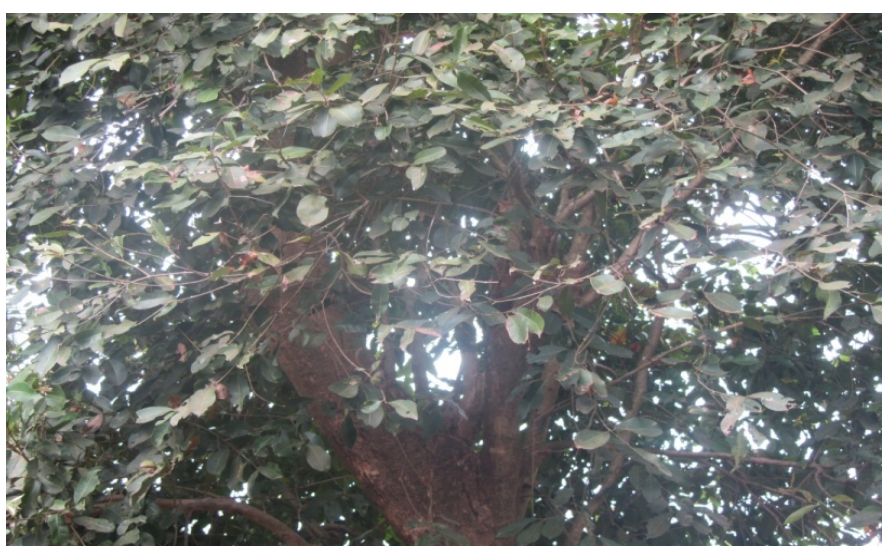

Syzygium cumini (L.)Skeels.

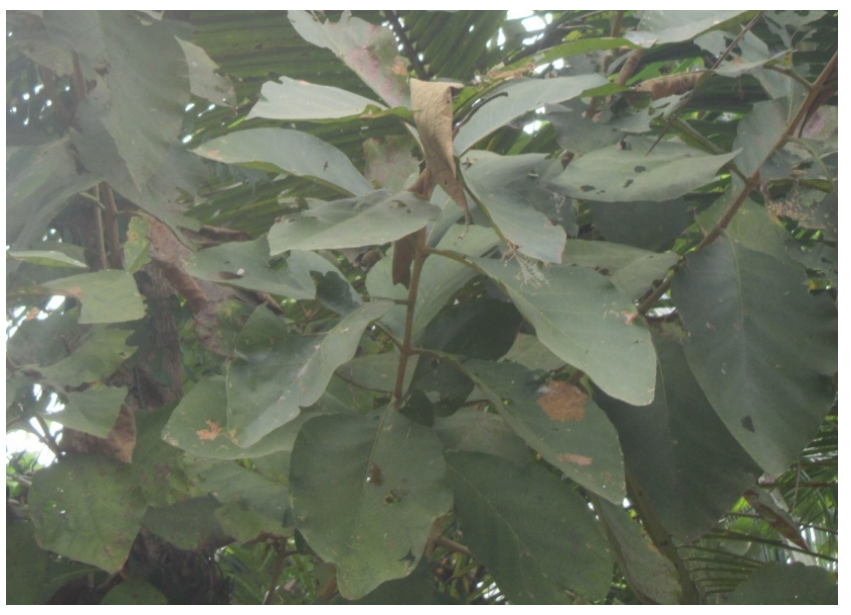

Tectona grandis L.f. 
PLATE 14

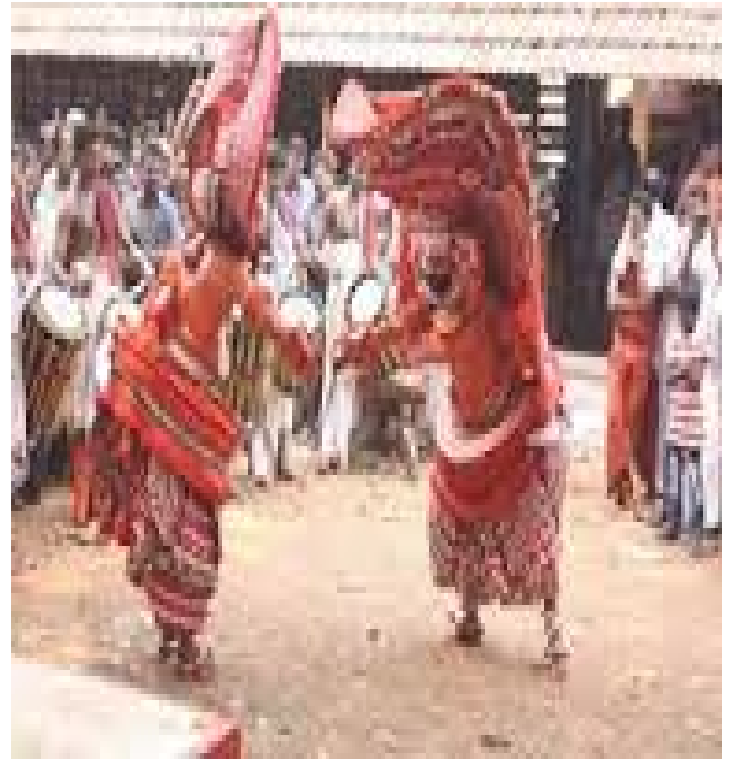

a) Ilamkarumakan and Poothadi

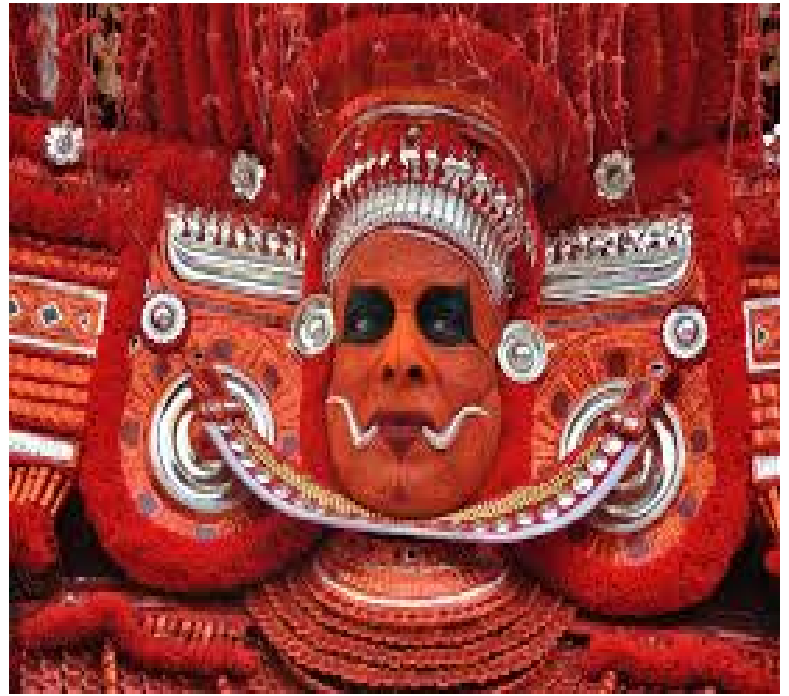

b) Thamburaatti

Festival

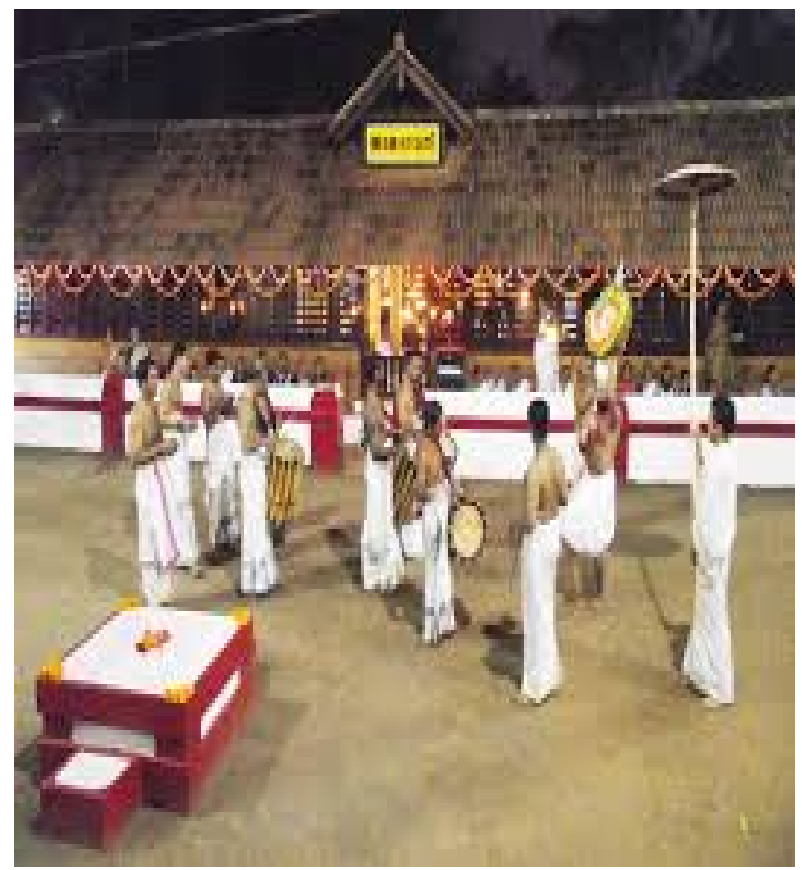

c) Kalasham

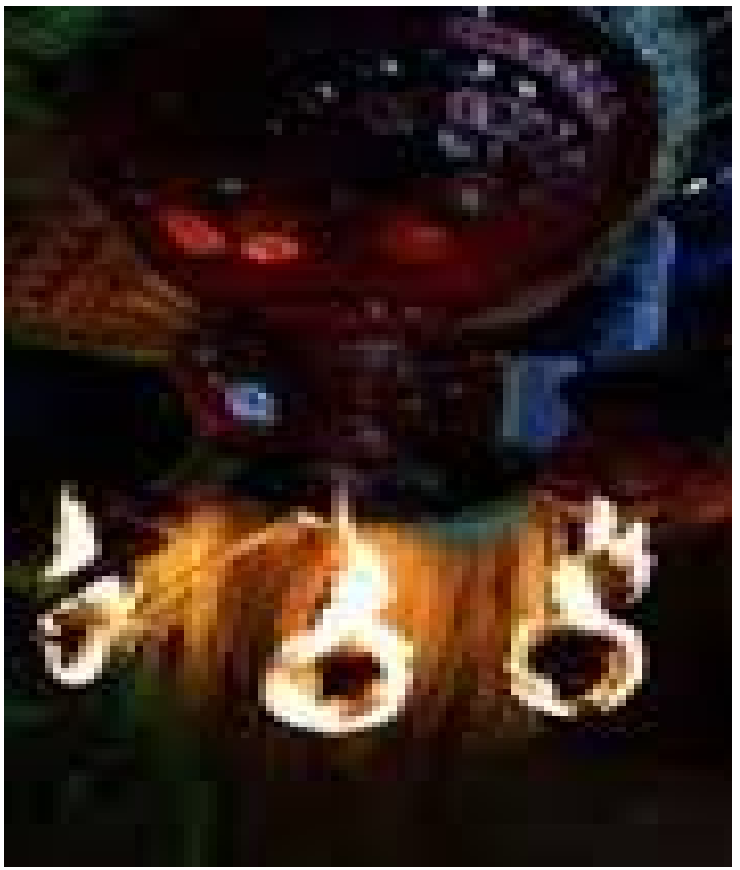

d) Thee Thira 
TABLE 1: Different plants seen in punikkol kavu

\begin{tabular}{|c|c|c|c|c|c|}
\hline & $\begin{array}{l}\text { NAME OF THE } \\
\text { PLANT }\end{array}$ & FAMILY & HABIT & $\begin{array}{l}\text { PARTS } \\
\text { USED }\end{array}$ & USES \\
\hline 1. & $\begin{array}{l}\text { Acmella ciliate (Kunth) } \\
\text { Cass. }\end{array}$ & Asteraceae & Herb & Flower & $\begin{array}{l}\text { It is an ornamental plant. } \\
\text { Used as an insecticide and as a herbal remedy } \\
\text { for toothache and oral infections. }\end{array}$ \\
\hline 2. & $\begin{array}{l}\text { Aglaia elaeagnoidea } \\
\text { (A.Juss) Benth. }\end{array}$ & Meliaceae & Tree & Fruits & $\begin{array}{l}\text { Antidiarrhoeal, alterative, astringent tonic, in } \\
\text { leprosy, burning sensation. }\end{array}$ \\
\hline 3. & $\begin{array}{l}\text { Amorphophallus } \\
\text { paeoniifolius (Dennst.) } \\
\text { Nicolson. }\end{array}$ & Araceae & Herb & Tuber & Used as food. \\
\hline 4. & $\begin{array}{l}\text { Anamirta coculus (L.) } \\
\text { Wight \& Arn. }\end{array}$ & $\begin{array}{l}\text { Menispermace } \\
\text { ae }\end{array}$ & Climber & Seeds & $\begin{array}{l}\text { Crushed seeds are effective pediculicide. } \\
\text { Traditionally used as a pesticide. }\end{array}$ \\
\hline 5. & Areca catechu L. & Aracaceae & Tree & Entire plant & Extract have anti depressant properties. \\
\hline 6. & $\begin{array}{l}\text { Arundinella purpurea } \\
\text { Hochst.ex Steud. }\end{array}$ & Poaceae & Herb & - & - \\
\hline 7. & $\begin{array}{l}\text { Arundinella setosa } \\
\text { Trin. }\end{array}$ & Poaceae & Herb & - & - \\
\hline 8. & $\begin{array}{l}\text { Biophytum sensitivum } \\
\text { (L.)DC }\end{array}$ & Oxalidaceae & Herb & Entire plant & $\begin{array}{l}\text { Extracts are antibacterial, anti Inflammatory, } \\
\text { antioxidant, antitumor, radio protective, ant } \\
\text { metastatic, ant angiogenesis, wound healing, } \\
\text { immunomodulation, anti diabetic and cardio } \\
\text { protective in nature. }\end{array}$ \\
\hline 9. & $\begin{array}{l}\text { Caesalpinia mimosidus } \\
\text { Lam. }\end{array}$ & Fabaceae & $\begin{array}{l}\text { Woody } \\
\text { climber }\end{array}$ & Roots, stem & Gallic acid is extracted from the plant. \\
\hline
\end{tabular}




\begin{tabular}{|c|c|c|c|c|c|}
\hline 10 & Carica papaya L. & Caricaceae & Tree & $\begin{array}{l}\text { Stem, bark, } \\
\text { fruit, leaves }\end{array}$ & $\begin{array}{l}\text { Fruit edible. } \\
\text { Stem and bark are used for crop production. } \\
\text { Leaves used in malaria. }\end{array}$ \\
\hline 11. & Caryota urens L. & Arecaceae & Palm & - & Ornamental plant \\
\hline 12 & Cassia fistula L. & Fabaceae & Tree & $\begin{array}{l}\text { Fruit, } \\
\text { leaves }\end{array}$ & $\begin{array}{l}\text { Fruit pulp is considered as puragative leaves is } \\
\text { used in relieving skin irritation. It is also an } \\
\text { ornamental plant. }\end{array}$ \\
\hline 13. & $\begin{array}{l}\text { Centrosema molle } \\
\text { Benth. }\end{array}$ & Fabaceae & Climber & - & Help in nitrogen fixation \\
\hline 14. & $\begin{array}{l}\text { Charsalia curviflora } \\
\text { (Wall.ex } \\
\text { Kurz)Thvaiten }\end{array}$ & Rubiaceae & Shrub & $\begin{array}{l}\text { Leaves } \\
\text {,root }\end{array}$ & $\begin{array}{l}\text { Used in ear infection, eye diseases, insect bite } \\
\text {,snake bite, ulcers wound etc. }\end{array}$ \\
\hline 15 & $\begin{array}{l}\text { Chromolaena odorata } \\
\text { King. }\end{array}$ & Asteraceae & Shrub & Entire plant & Used in burns, skin diseases and wounds. \\
\hline 16. & Cissus latifolia Lam. & Vitaceae & Climber & Root & Used in cardiovascular diseases. \\
\hline 17. & Cleome viscose $\mathrm{L}$. & Capparaceae & Herb & Leaves & $\begin{array}{l}\text { Used in the treatment of wounds, ulcer and to } \\
\text { relive ear ache. }\end{array}$ \\
\hline 18 & Cocos nucifera L. & Aracaceae & Tree & $\begin{array}{l}\text { Entire } \\
\text { plant }\end{array}$ & $\begin{array}{l}\text { Use as food, Flower provide good honey, Used } \\
\text { as folk remedy for tumors. }\end{array}$ \\
\hline 19. & $\begin{array}{l}\text { Cosmostigma } \\
\text { racemosum } \\
\text { (Roxb.)Wight. }\end{array}$ & Asclepidiaceae & $\begin{array}{l}\text { Twining } \\
\text { shrub }\end{array}$ & Leaves & Cure ulcerous sores. \\
\hline 20 & $\begin{array}{l}\text { Curcuma aromatic } \\
\text { Salisb. }\end{array}$ & Zingiberaceae & Shrub & Rhizome & $\begin{array}{l}\text { Applied wounds and injuries. Used for } \\
\text { respiratory infections and disorder. Used to } \\
\text { enhance face beauty. }\end{array}$ \\
\hline 21 & $\begin{array}{l}\text { Cyclea peltata (Lam.) } \\
\text { Hookf.\&Thomson }\end{array}$ & $\begin{array}{l}\text { Menispermace } \\
\text { ae }\end{array}$ & climber & Root & $\begin{array}{l}\text { Used in the preparation of medicated ghee and } \\
\text { decoction for viper bite. }\end{array}$ \\
\hline 22 & $\begin{array}{l}\text { Cynodon dactylon } \\
\text { (L.)Pers. }\end{array}$ & Araceae & Herb & Entire plant & $\begin{array}{l}\text { Used in the treatment of wounds, injuries, eye } \\
\text { problems, skin rashes, diabetes etc. }\end{array}$ \\
\hline
\end{tabular}


South American Journal of Medicine Special Edition 2016

\begin{tabular}{|c|c|c|c|c|c|}
\hline 23 & $\begin{array}{l}\text { Diplocyclos palmatus } \\
\text { (L.)Jeffrey. }\end{array}$ & Cucurbitaceae & climber & Entire plant & $\begin{array}{l}\text { Used in the treatment of cough, skin diseases, } \\
\text { swelling, spleen, and esophagus diseases. }\end{array}$ \\
\hline 24 & $\begin{array}{l}\text { Drynaria quercifolia } \\
\text { (Linn.) J.Smith. }\end{array}$ & Polypodiaceae & Fern & Rhizome & $\begin{array}{l}\text { Rhizomes are used in cough, typhoid, diarrhea, } \\
\text { migraine and headache. }\end{array}$ \\
\hline 25 & Elephantopus scaber L. & Asteraceae & Herb & Entire plant & Used to reduce fever, ulcer. rheumatism etc. \\
\hline 26 & $\begin{array}{l}\text { Emilia sonchifolia (L.) } \\
\text { DC.ex Wight }\end{array}$ & Asteraceae & Herb & Entire plant & Used in the treatment of Indian Krait. \\
\hline 27 & Ficus religiosa (L.) & Moraceae & Tree & $\begin{array}{l}\text { Bark, } \\
\text { leaves, } \\
\text { fruits. }\end{array}$ & $\begin{array}{l}\text { Bark is used as an antibacterial, antiprotozoal } \\
\text { and also in the treatment of ulcer. Leaves are } \\
\text { used in the treatment of skin disease. Fruits are } \\
\text { used as laxatives. }\end{array}$ \\
\hline 28 & $\begin{array}{l}\text { Gliricidia sepium } \\
\text { (Jacq.) Kunth ex walp. }\end{array}$ & Fabaceae & Tree & Entire plant & $\begin{array}{l}\text { Tree is used for fencing, fodder, coffee shade. } \\
\text { Leaves are used to remove external parasites. }\end{array}$ \\
\hline 29 & $\begin{array}{l}\text { Glycosmis mauritiana } \\
\text { Tanaka. }\end{array}$ & Rutaceae & Shrub & $\begin{array}{l}\text { Entire } \\
\text { plant }\end{array}$ & $\begin{array}{l}\text { Leucorrhoea, arthritis, urinary infection, cough } \\
\text { etc. }\end{array}$ \\
\hline 30 & $\begin{array}{l}\text { Glycosmis pentaphylla } \\
\text { (Retl.) DC. }\end{array}$ & Rutaceae & Small tree & Fruits & $\begin{array}{l}\text { Fruits edible. } \\
\text { Plant has wound healing properties. }\end{array}$ \\
\hline 31 & Grewia hirsute Vah. & Tiliaceae & Herb & $\begin{array}{l}\text { Root, } \\
\text { leaves }\end{array}$ & $\begin{array}{l}\text { Used in the treatment of heart diseases, nerve } \\
\text { diseases, pain relief etc. }\end{array}$ \\
\hline 32 & Grewia nervosa (Lour.) & Tiliaceae & Shrub & $\begin{array}{l}\text { Leaves, } \\
\text { bark }\end{array}$ & Used in the treatment of diabetes. \\
\hline 33 & $\begin{array}{l}\text { Heliotropium indicum } \\
\text { L. }\end{array}$ & Boraginaceae & Herb & Leaves & Leaf juice is used on wounds, skin ulcers etc. \\
\hline 34 & $\begin{array}{l}\text { Hyptis suaveolens }(\mathrm{L} .) \\
\text { Poit. }\end{array}$ & Lamiaceae & Herb & Entire plant & $\begin{array}{l}\text { It is an effective insecticide. It can be made in to } \\
\text { a refreshing drink by soaking the seeds in water. } \\
\text { Rationally it is used in the treatment of diarrhea. }\end{array}$ \\
\hline 35 & $\begin{array}{l}\text { Ichnocarpus } \\
\text { frutescence (L.)R.Br. }\end{array}$ & Apocynaceae & Shrub & Root, bark & $\begin{array}{l}\text { Treatment of rheumatism, asthma, cholera and } \\
\text { fever. } \\
\text { Bark is used for making rope. }\end{array}$ \\
\hline 36 & Ixora coccinia $\mathrm{L}$. & Rubiaceae & shrub & Entire plant & $\begin{array}{l}\text { Ayurvedic medicine. Flowers are used for } \\
\text { worshipping God. }\end{array}$ \\
\hline
\end{tabular}




\begin{tabular}{|c|c|c|c|c|c|}
\hline 37. & Lantana camara Linn. & Verbenaceae & Shrub & Entire plant & $\begin{array}{l}\text { It has antimicrobial, fungicidal and insecticidal } \\
\text { properties. It is also used as herbal medicine in } \\
\text { treatment of leprosy, chickenpox, ulcers etc. }\end{array}$ \\
\hline 38. & $\begin{array}{l}\text { Legerstromia } \\
\text { microcarpa Wight. }\end{array}$ & Lythraceae & Tree & Wood & Used for construction, ship building etc. \\
\hline 39. & $\begin{array}{l}\text { Leucas lavandulifolia } \\
\text { L. }\end{array}$ & Lamiaceae & Herb & Leaves & $\begin{array}{l}\text { Antifungal, prostaglandin inhibitory antioxidant } \\
\text { antimicrobial, antinociceptive and cytotoxic } \\
\text { activities. Also it is used as insecticide. }\end{array}$ \\
\hline 40 & $\begin{array}{l}\text { Loranthus ferrugineus } \\
\text { Roxb. }\end{array}$ & Loranthaceae & Climber & $\begin{array}{l}\text { Leaves, } \\
\text { fruits, } \\
\text { flowers. }\end{array}$ & $\begin{array}{l}\text { Used for the management of hypertension, } \\
\text { treatment of malaria, and used for wounds. }\end{array}$ \\
\hline 41 & $\begin{array}{l}\text { Macaranga peltata } \\
\text { Roxb. Mueller }\end{array}$ & Euphorbiaceae & Tree & $\begin{array}{l}\text { Leaves, } \\
\text { wood }\end{array}$ & $\begin{array}{l}\text { Used as flavouring agent. Also used in pencil } \\
\text { industry. }\end{array}$ \\
\hline 42 & $\begin{array}{l}\text { Mallotus philippensis } \\
\text { (Lam.) Mull-Arg. }\end{array}$ & Euphorbiaceae & Tree & Entire plant & Produce red eye and herbal medicine. \\
\hline 43. & Mangifera indica $\mathrm{L}$. & Anacardiaceae & Tree & $\begin{array}{l}\text { Fruits, } \\
\text { seeds }\end{array}$ & $\begin{array}{l}\text { Used in ayurvedic medicine, It possess ant } \\
\text { diabetic, anti oxidant, anti-viral, cardio tonic, } \\
\text { hypotansive and anti inflammatory properties. }\end{array}$ \\
\hline 44 & Mimosa pudica L. & Leguminosae & Herb & Entire plant & $\begin{array}{l}\text { Used in the treatment of diarrhea, ulcers, piles, } \\
\text { sinus, insect bite etc. }\end{array}$ \\
\hline 45 & Mimusops elengi Linn. & Sapotaceae & Tree & $\begin{array}{l}\text { Bark, } \\
\text { flowers } \\
\text { seeds, } \\
\text { fruits }\end{array}$ & $\begin{array}{l}\text { Used in dental ailments like bleeding gums, } \\
\text { pyorrhea, dental caries and loose teeth. } \\
\text { Extract of flowers are used against heart } \\
\text { diseases, leucorrhoea, menorrhagia and act as } \\
\text { diuretic. } \\
\text { Decoction of bark is used to wash the wounds. }\end{array}$ \\
\hline 46 & $\begin{array}{l}\text { Mucuna pruriens } \\
\text { (L.)DC. }\end{array}$ & Fabaceae & $\begin{array}{l}\text { Climbing } \\
\text { shrub }\end{array}$ & Entire plant & Used in Parkinson's disease. \\
\hline 47 & Musa paradisiacal L. & Musaceae & Herb & Entire plant & $\begin{array}{l}\text { Used as food. } \\
\text { Root is anthelmintic. }\end{array}$ \\
\hline 48. & Mussaenda frondosa $\mathrm{L}$. & Rubiaceae & Shrub & Entire plant & Used in treatment of injuries, disorders of bones \\
\hline
\end{tabular}


South American Journal of Medicine

Special Edition 2016

\begin{tabular}{|c|c|c|c|c|c|}
\hline & & & & & and joints etc. \\
\hline 49. & Ocimum sanctum L. & Lamiaceae & Shrub & $\begin{array}{l}\text { Leaves, } \\
\text { seeds }\end{array}$ & $\begin{array}{l}\text { Used in religious purposes. It is regarded as an } \\
\text { elixir of life and is believed to increase } \\
\text { longevity. Used in skin treatments. }\end{array}$ \\
\hline 50 & Ocimum tenuiflorum $\mathrm{L}$. & Lamiaceae & Shrub & $\begin{array}{l}\text { Leaves, } \\
\text { seed }\end{array}$ & $\begin{array}{l}\text { Used in the treatment of problems of digestive } \\
\text { and nerves, head ache, nausea, kidney stones etc. }\end{array}$ \\
\hline 51 & $\begin{array}{l}\text { Pajanelia longifolia } \\
\text { (Wild.) K.Schum }\end{array}$ & Bignoniaceeae & Tree & Leaves & Treatment of fever, stomach disorders etc. \\
\hline 52 & Phyllanthus emblica L. & Euphorbiaceae & Tree & Entire plant & $\begin{array}{l}\text { Fruit is edible. Reduce cholesterol. Balancs three } \\
\text { doshas. } \\
\text { Used for hair growth. }\end{array}$ \\
\hline 53. & $\begin{array}{l}\text { Phyllanthus niruri } \\
\text { Linn. }\end{array}$ & Euphorbiaceae & Herb & Entire plant & $\begin{array}{l}\text { Used in hair growth, treatment of jaundice and } \\
\text { liver related diseases. }\end{array}$ \\
\hline 54 & Piper betle L. & Piperaceae & Climber & Leaves & $\begin{array}{l}\text { Used as a stimulant, antiseptic and breath } \\
\text { freshener. }\end{array}$ \\
\hline 55. & Piper nigram L. & Piperaceae & Climber & $\begin{array}{l}\text { Dried } \\
\text { unripe } \\
\text { fruits }\end{array}$ & $\begin{array}{l}\text { Oil is used in the treatment of pain relief, } \\
\text { rheumatism, chills etc. Also used in diarrhea, } \\
\text { cholera, scarlatina etc. }\end{array}$ \\
\hline 56. & $\begin{array}{l}\text { Plumeria rubra } \\
\text { acutifolia Poir. }\end{array}$ & Mangoliaceae & Small tree & $\begin{array}{l}\text { Root, } \\
\text { leaves, } \\
\text { bark }\end{array}$ & $\begin{array}{l}\text { Plant is considered as sacred. Used for skin } \\
\text { diseases, inflammations, arthritis etc. }\end{array}$ \\
\hline 57 & Pothos scandens L. & Araceae & Climber & $\begin{array}{l}\text { Root, } \\
\text { leaves }\end{array}$ & $\begin{array}{l}\text { Promote healing of abscesses. Used to treat } \\
\text { asthma. }\end{array}$ \\
\hline 58 & Rourea minor Leenh. & Connaraceae & Climber & $\begin{array}{l}\text { Fruit, bark, } \\
\text { root, seed, } \\
\text { leaves. }\end{array}$ & $\begin{array}{l}\text { Used in diabetes, scurvy, skin diseases, stomach } \\
\text { ache, ulcer etc. }\end{array}$ \\
\hline 59. & Sida acuta Burm.f. & Malvaceae & Herb & $\begin{array}{l}\text { Roots, } \\
\text { leaves }\end{array}$ & $\begin{array}{l}\text { Roots are used as coolant, astringent, } \\
\text { diaphoretic, antipyretic and tonic. It is useful in } \\
\text { nervous and urinary diseases and in the disorders } \\
\text { of blood and bile. } \\
\text { Leaves are demulcent and diuretic. }\end{array}$ \\
\hline
\end{tabular}




\begin{tabular}{|c|c|c|c|c|c|}
\hline 60 & Sida alnifolia $\mathrm{L}$. & Malvaceae & Herb & $\begin{array}{l}\text { Leaves, } \\
\text { roots }\end{array}$ & $\begin{array}{l}\text { Balances all the doshas-vata, pita, kapha } \\
\text { Useful in piles } \\
\text { Roots are regarded as cooling, astringent, tonic, } \\
\text { bitter febrifuge, demulcent and diuretic. }\end{array}$ \\
\hline 61. & $\begin{array}{l}\text { Strychnos nux-vomica } \\
\text { Linn. }\end{array}$ & Loganiaceae & Tree & Entire plant & $\begin{array}{l}\text { Prepare powerful medicine in toxicology. Cure } \\
\text { headache caused due to snakebite }\end{array}$ \\
\hline 62 & $\begin{array}{l}\text { Synedrella nudiflora } \\
\text { (L.) Gaertn. }\end{array}$ & Asteraceae & Herb & Entire plant & Used to treat epilepsy. \\
\hline 63. & Tectona grandis L.f. & Lamiaceae & Tree & Wood, bark & $\begin{array}{l}\text { Used for boat building, exterior construction, } \\
\text { furniture carving etc. Tonic made from bark is } \\
\text { used to cure fever, Also useful in headache and } \\
\text { stomach pain. }\end{array}$ \\
\hline 64 & Terminalia catapa L. & Combretaceae & Tree & $\begin{array}{l}\text { Leaves, } \\
\text { fruits }\end{array}$ & $\begin{array}{l}\text { Treat liver diseases. } \\
\text { Fruits edible. }\end{array}$ \\
\hline 65. & $\begin{array}{l}\text { Triemfetta rhomboidea } \\
\text { Lam. }\end{array}$ & Tiliaceae & Herb & $\begin{array}{l}\text { Fruits, } \\
\text { flowers, } \\
\text { leaves }\end{array}$ & Used as demulcent and astringent. \\
\hline 66. & Urena lobata L. & Malvaceae & Undershrub & $\begin{array}{l}\text { Roots, } \\
\text { leaves }\end{array}$ & $\begin{array}{l}\text { Used to treat skin diseases, dysentery, rheumatic } \\
\text { pain, tonsillitis etc. }\end{array}$ \\
\hline 67 & Vetiveria zizanioides L. & Poaceae & Herb & Root & $\begin{array}{l}\text { Used to treat swelling and pain in joints, fever, } \\
\text { jaundice etc. }\end{array}$ \\
\hline 68 & $\begin{array}{l}\text { Watakkaka volubilis } \\
\text { stapf. }\end{array}$ & Asclepiadaceae & $\begin{array}{l}\text { Woody } \\
\text { climber }\end{array}$ & $\begin{array}{l}\text { Roots, } \\
\text { leaves }\end{array}$ & $\begin{array}{l}\text { Used against skin diseases, diabetes, coughs, } \\
\text { jaundice, poison bites and purifying blood. }\end{array}$ \\
\hline 69. & $\begin{array}{l}\text { Xenostegia tridentate } \\
\text { (L.) Aushin\&Staples. }\end{array}$ & $\begin{array}{l}\text { Convolvulacea } \\
\text { e }\end{array}$ & Creeper & Entire plant & Used in the treatment of urinary infection. \\
\hline 70 & $\begin{array}{l}\text { Ziziphus oenopolia }(\mathrm{L} .) \\
\text { Mill }\end{array}$ & Rhamnaceae & Shrub & Fruit, bark & $\begin{array}{l}\text { Berries are edible. } \\
\text { Bark is used for tanning. } \\
\text { Used in the treatment malaria. }\end{array}$ \\
\hline
\end{tabular}


TABLE 2: Different plants seen in chirakkakavu

\begin{tabular}{|c|c|c|c|c|c|}
\hline & $\begin{array}{l}\text { NAME OF THE } \\
\text { PLANT }\end{array}$ & FAMILY & HABIT & $\begin{array}{l}\text { PARTS } \\
\text { USED }\end{array}$ & USES \\
\hline 1. & Adenanthera pavonina L. & Fabaceae & Tree & $\begin{array}{l}\text { Leaves, } \\
\text { seed, bark }\end{array}$ & $\begin{array}{l}\text { It is useful for nitrogen fixation, Leaves can } \\
\text { be eaten, Decoction of young leaves and bark } \\
\text { are used to treat diarrhea. }\end{array}$ \\
\hline 2. & Alstonia scolaris $\mathrm{R} . \mathrm{Br}$. & Apocynaceae & Tree & $\begin{array}{l}\text { Leaves, } \\
\text { bark }\end{array}$ & $\begin{array}{l}\text { Purify blood and treatment of respiratory } \\
\text { disorders, and to stop cancerous growth. }\end{array}$ \\
\hline 3. & $\begin{array}{l}\text { Anacardium occidentale } \\
\text { L. }\end{array}$ & Anacardiaceae & Tree & $\begin{array}{l}\text { Fruit, } \\
\text { seeds, } \\
\text { timber, } \\
\text { bark }\end{array}$ & $\begin{array}{l}\text { Fruits and seeds are edible. Timber is used in } \\
\text { furniture making. Bark is used in tanning. } \\
\text { Used in the treatment of cancerous ulcers, } \\
\text { diarrhea, malaria etc. }\end{array}$ \\
\hline 4. & $\begin{array}{l}\text { Anisochilus carnosus } \\
\text { L.f.)Wall.ex Benth }\end{array}$ & Lamiaceae & Herb & $\begin{array}{l}\text { Leaves, } \\
\text { spike }\end{array}$ & Used in the treatment of ulcer. \\
\hline 5. & Areca catechu L. & Aracaceae & Tree & Entire plant & $\begin{array}{l}\text { Extract have anti depressant properties in } \\
\text { rodents. It is commercially important seed } \\
\text { crop. }\end{array}$ \\
\hline 6. & $\begin{array}{l}\text { Artocarpus heterophyllus } \\
\text { Lam. }\end{array}$ & Moraceae & Tree & $\begin{array}{l}\text { Fruit, } \\
\text { leaves, } \\
\text { seeds }\end{array}$ & $\begin{array}{l}\text { Fruit is edible. Curing fever, boils, skin } \\
\text { diseases, skin diseases, diarrhea etc. }\end{array}$ \\
\hline 7. & $\begin{array}{l}\text { Bambusa bambos } \\
\text { (L.)Voss }\end{array}$ & Poaceae & Perennial & $\begin{array}{l}\text { Leaves, } \\
\text { stem }\end{array}$ & $\begin{array}{l}\text { Manufacturing different household products. } \\
\text { Used to treat various inflammatory } \\
\text { conditions. Also used in the treatment of } \\
\text { kidney troubles. }\end{array}$ \\
\hline 8. & Bauhinia acuminate L. & Fabaceae & Shrub & $\begin{array}{l}\text { Bark, } \\
\text { flower, root }\end{array}$ & $\begin{array}{l}\text { Used in skin diseases. } \\
\text { It is grown as an ornamental plant. }\end{array}$ \\
\hline 9. & Careya arborea Roxb. & Lecythidaceae & Tree & $\begin{array}{l}\text { Bark, } \\
\text { flowers }\end{array}$ & Used for the treatment of cold and cough. \\
\hline
\end{tabular}




\begin{tabular}{|c|c|c|c|c|c|}
\hline 10. & Carica papaya L. & Caricaceae & Tree & $\begin{array}{l}\text { Stem, } \\
\text { Bark, } \\
\text { fruit, leaves }\end{array}$ & $\begin{array}{l}\text { Fruit edible. } \\
\text { Stem and bark are used for crop production. } \\
\text { Leaves used in malaria. }\end{array}$ \\
\hline 11. & Caryota urens L. & Arecaceae & Palm & - & Ornamental plant \\
\hline 12. & $\begin{array}{l}\text { Chromolaena odorata (L.) } \\
\text { King \& H.E.Robins }\end{array}$ & Asteraceae & Shrub & Entire plant & Used in burns, skin diseases and wounds. \\
\hline 13. & Cocos nucifera $\mathrm{L}$. & Aracaceae & Tree & Entire plant & $\begin{array}{l}\text { Providing food, Flower provide good honey, } \\
\text { Used as folk remedy for tumors. }\end{array}$ \\
\hline 14. & $\begin{array}{l}\text { Desmodium gangaticum } \\
\text { (L.)DC. }\end{array}$ & Fabaceae & Undershrub & $\begin{array}{l}\text { Root, bark, } \\
\text { Leaves. }\end{array}$ & Used in fevers, oedema, kidney disorders etc. \\
\hline 15. & $\begin{array}{l}\text { Elaeocarpus sphaerius } \\
\text { (Gaerth) K.schum }\end{array}$ & Elaeocarpaceae & Tree & $\begin{array}{l}\text { Fruit, } \\
\text { leaves }\end{array}$ & $\begin{array}{l}\text { Used to treat fever, cold or cough. treating } \\
\text { wounds, epilepsy etc. }\end{array}$ \\
\hline 16. & Elephantopus scaber L. & Asteraceae & Herb & Entire plant & Used to reduce fever, ulcer. rheumatism etc. \\
\hline 17. & Ficas religiosa $(\mathrm{L})$. & Moraceae & Tree & $\begin{array}{l}\text { Bark, } \\
\text { leaves, } \\
\text { fruits. }\end{array}$ & $\begin{array}{l}\text { Bark is used as an antibacterial, antiprotozoal } \\
\text { and also in the treatment of ulcer. Leaves are } \\
\text { used in the treatment of skin disease. Fruits } \\
\text { are used as laxatives. }\end{array}$ \\
\hline 18. & Ficus benghalensis L. & Moraceae & Tree & Entire plant & $\begin{array}{l}\text { Plant is considered as sacred. Help in soil } \\
\text { conservation. Used to make furniture. } \\
\text { Also used in the treatment of ulcer } \\
\text {,inflammations, fever etc. }\end{array}$ \\
\hline 19. & Heliotropium indicum L. & Boraginaceae & Herb & Leaves & Leaf juice is on wounds, skin ulcers etc. \\
\hline 20. & Hibiscus rosasinensis L. & Rubiaceae & Shrub & $\begin{array}{l}\text { Leaves, } \\
\text { flowers }\end{array}$ & $\begin{array}{l}\text { It is grown as ornamental plant. } \\
\text { Used for hair growth. Also flowers are edible. } \\
\text { Used for skin diseases. Flowers are used for } \\
\text { worshipping Devi. }\end{array}$ \\
\hline 21. & $\begin{array}{l}\text { Holigarna arnottiana } \\
\text { Hook.f. }\end{array}$ & Anacardiaceae & Tree & Seeds & Increase body power. \\
\hline 22. & Ixora coccinia L. & Rubiaceae & shrub & Entire plant & Ayurvedic medicine. \\
\hline 23. & $\begin{array}{l}\text { Macaranga peltata Roxb. } \\
\text { Mueller }\end{array}$ & Euphorbiaceae & Tree & $\begin{array}{l}\text { Leaves, } \\
\text { wood }\end{array}$ & $\begin{array}{l}\text { Used as flavouring agent. Also used in pencil } \\
\text { industry. }\end{array}$ \\
\hline
\end{tabular}


South American Journal of Medicine

Special Edition 2016

\begin{tabular}{|c|c|c|c|c|c|}
\hline 24. & Mangifera indica $\mathrm{L}$. & Anacardiaceae & Tree & Fruit & $\begin{array}{l}\text { Clear acidity, treat skin diseases, snakebite, } \\
\text { wounds etc. Fruit is edible. }\end{array}$ \\
\hline 25. & Microcos paniculata L. & Tiliaceae & Shrub & Leaves & $\begin{array}{l}\text { Used in the treatment of jaundice, small pox, } \\
\text { typhoid fever etc. }\end{array}$ \\
\hline 26. & Mimosa pudica & Leguminosae & Herb & Entire plant & $\begin{array}{l}\text { Used in the treatment of diarrhea, ulcers, } \\
\text { piles, sinus, insect bite etc. }\end{array}$ \\
\hline 27. & Mimusops elengi Linn. & Sapotaceae & Tree & $\begin{array}{l}\text { Bark, } \\
\text { flowers } \\
\text { seeds, } \\
\text { fruits }\end{array}$ & $\begin{array}{l}\text { Used in dental ailments like bleeding gums, } \\
\text { pyorrhea, dental caries and loose teeth. } \\
\text { Extract of flowers are used against heart } \\
\text { diseases, leucorrhoea, menorrhagia and act as } \\
\text { diuretic. } \\
\text { Decoction of bark is used to wash the } \\
\text { wounds. }\end{array}$ \\
\hline 28. & Naregamia alata W\&A. & Meliaceae & Herb & Entire plant & $\begin{array}{l}\text { Used in the treatment of dysentery and } \\
\text { rheumatism. }\end{array}$ \\
\hline 29. & Pothos scandens L. & Araceae & Climber & $\begin{array}{l}\text { Root, } \\
\text { leaves }\end{array}$ & $\begin{array}{l}\text { Promote healing of abscesses. Used to treat } \\
\text { asthma. }\end{array}$ \\
\hline 30. & Ruellia tuberose L. & Acanthaceae & Herb & - & Used as an ornamental plant \\
\hline 31. & Scoparia dulsis L. & Scrophulariaceae & Herb & Entire plant & $\begin{array}{l}\text { Used in the treatment of urinary bladder } \\
\text { stone. }\end{array}$ \\
\hline 32. & Setaria parviflora L. & Poaceae & Herb & - & - \\
\hline 33. & Sida acuta Burm.f. & Malvaceae & Herb & $\begin{array}{l}\text { Roots, } \\
\text { Leaves }\end{array}$ & $\begin{array}{l}\text { Roots are used as coolant, astringent, } \\
\text { diaphoretic, antipyretic and tonic. It is useful } \\
\text { in nervous and urinary diseases and in the } \\
\text { disorders of blood and bile. } \\
\text { Leaves are demulcent and diuretic. }\end{array}$ \\
\hline 34. & Sida rhombifolia L. & Malvaceae & Herb & $\begin{array}{l}\text { Leaves, } \\
\text { roots }\end{array}$ & $\begin{array}{l}\text { Balances all the doshas-vata, pita, kapha } \\
\text { Useful in piles } \\
\text { Roots are regarded as cooling, astringent, } \\
\text { tonic, bitter febrifuge, demulcent and diuretic. }\end{array}$ \\
\hline 35. & Strychnos nux-vomica & Loganiaceae & Tree & Entire plant & Prepare powerful medicine in toxicology. \\
\hline
\end{tabular}


South American Journal of Medicine Special Edition 2016

\begin{tabular}{|c|c|c|c|c|c|}
\hline & Linn. & & & & Cure headache caused due to snakebite. \\
\hline 36. & $\begin{array}{l}\text { Syzygium cumini } \\
\text { (L.)Skeels. }\end{array}$ & Myrtaceae & Tree & Fruit, seeds & Fruit is edible. Seeds are used to reduce sugar. \\
\hline 37. & Tectona grandis L.f. & Lamiaceae & Tree & Wood, bark & $\begin{array}{l}\text { Used for boat building, exterior construction, } \\
\text { furniture carving etc. Tonic made from bark is } \\
\text { used to cure fever. Also useful in headache } \\
\text { and stomach pain. }\end{array}$ \\
\hline 38. & Tridax procumbance $\mathrm{L}$. & Asteraceae & Herb & Entire plant & $\begin{array}{l}\text { Used in the treatment of diarrhoea, dysentery, } \\
\text { skin diseases, liver disorders, wound healing } \\
\text { etc. }\end{array}$ \\
\hline 39. & Vanda sp. & Orchidaceae & Epiphyte & - & - \\
\hline 40. & Vernonia cinerea Less. & Asteraceae & Herb & Entire plant & $\begin{array}{l}\text { Used in the treatment of fever, urinary } \\
\text { obstruction and scorpion sting. }\end{array}$ \\
\hline 41. & Zizipus oenopolia (L.)Mill & Rhamnaceae & Shrub & Fruit, bark & $\begin{array}{l}\text { Berries are edible. } \\
\text { Bark is used for tanning. } \\
\text { Used in the treatment malaria. }\end{array}$ \\
\hline
\end{tabular}


TABLE 3: Plants in groves which are used for worshipping god

\begin{tabular}{|c|c|c|}
\hline S.NO & NAME OF THE PLANT & USES \\
\hline 1. & Bauhinia acuminate $\mathrm{L}$. & The flowers are white in colour and are used for pooja purposes in Kerala. \\
\hline 2. & Cassia fistula $\mathrm{L}$. & $\begin{array}{l}\text { This is a golden yellow flower, which is a vital part of God Vishnu. It is used for } \\
\text { celebration related to Lord Vishnu. }\end{array}$ \\
\hline 3. & Elaeocarpus sphaerius L. & $\begin{array}{l}\text { Rudraksha names both a Sacred seed and the tree bears it. The seeds are considered as the } \\
\text { tears shed by Lord Shiva for the benefit of humanity. There are many stories about this. } \\
\text { One among them is following."Rudra wept when He witnessed the towering metropolies, } \\
\text { Tripura or triple city, created by man's superbly ambitious technology. In its arrogance, } \\
\text { this magnificent human creation has undermined the balance between the earth, } \\
\text { atmosphere and the sky. Then, according to Mahabharata, having shed the implacable tear } \\
\text { which turned in to a Rudraksha bead. The Lord of the Universe drew His bow and } \\
\text { unleashed His arrows at the triple city, burning its demons and hurling them into the } \\
\text { Western ocean for the welfare of creation. Wearing the Rudraksha, devotees remind } \\
\text { themselves of God's compassion for the human predicament, His watchful love for us. }\end{array}$ \\
\hline 4. & Ficus benghalensis L. & $\begin{array}{l}\text { Hindu mythology says that Brahma was transformed in to a Vat tree and it is viewed as the } \\
\text { male to the peepal. It is considered as a sin to destroy both the trees especially the male. }\end{array}$ \\
\hline 5. & Ficus religiosa $(\mathrm{L})$. & $\begin{array}{l}\text { The tree is considered Sacred by the followers of Hinduism, Jainism and Buddhism. } \\
\text { Sadhus still meditate beneath Sacred fig trees and Hindus do Pradakshina around the fig } \\
\text { tree as a mark of worship. Also this tree is closely related to Lord Krishna. The peepal is } \\
\text { believed to be inhabited by the Sacred triad-Brahma, Vishnu and Maheshwara. }\end{array}$ \\
\hline 6. & Hibiscus rosasinensis $\mathrm{L}$. & $\begin{array}{l}\text { Used for the worship of Devi. Red flowers are dominant. These are used or the } \\
\text { worshipping of other Gods also. }\end{array}$ \\
\hline
\end{tabular}




\begin{tabular}{|c|c|c|}
\hline 7. & Ixora coccinia $\mathbf{L}$. & $\begin{array}{l}\text { The plant is of a red shade and is thought of being Sacred. Therefore it is offered as prayers } \\
\text { in many temples in Kerala. }\end{array}$ \\
\hline 8. & Ocimum sanctum L. & $\begin{array}{l}\text { Holly basil is cultivated for medical and religious purposes and for its essential oil. In } \\
\text { particular, it has been used for Thousands of years in Ayurvedic medicine for various types } \\
\text { of healing.O.sanctum is considered an adaptogen, balancing the process of the body and } \\
\text { allowing it to adapt to stressful situations. It is regarded as an elixir of life and is believed } \\
\text { to promote longevity. The seeds are sometimes worn on the body in order to bring balance } \\
\text { and longevity. }\end{array}$ \\
\hline 9. & Plumeria rubra Poir. & It is one of the important plants for God Gulikan. It is used for worshipping God in Groves. \\
\hline 10. & Strychnos-nux vomica L. & $\begin{array}{l}\text { This is seen in almost all Sacred Groves. The tree is an important for the Lord Gulikan. } \\
\text { Leaves is used for worshipping God Sasthappan (pooya vaykkal). }\end{array}$ \\
\hline
\end{tabular}

